\title{
La mitad de oficios en concejos. Madridejos y otros casos, entre el Medievo y la Edad Moderna
}

\author{
Half of trades in councils. Madridejos and other cases, between \\ the Middle Ages and the Modern times
}

LUIS Díaz de LA GuARDIA y LÓPEZ*

RESUMEN

Bajo la excusa de los sucesos acontecidos en villas y lugares como Madridejos y otras poblaciones, tanto en los siglos XV como $X V I$, donde diversos grupos de personas cohesionados y formando estado solicitan,

exigen $y$, con frecuencia, consiguen por medio de litigio penetrar en las instituciones municipales, se realiza un estudio sobre la institución de la mitad de oficios, defendiendo su naturaleza no nobiliaria sino de Derecho público y estableciendo unos parámetros definitorios que puedan englobar a toda esta institución entendida tanto como tipología electoral y como tipología estructural de los concejos castellanos, así como derecho que puede ser alegado por nobles mayoritariamente-pero también por pecheros ya sean cristianos viejos o nuevos, labradores o caballeros villanos, pobres o ricos. De igual modo a través del presente análisis se demuestra la dificultad que en muchas ocasiones representaba conseguir el fin deseado y cómo los derrotados en los

pleitos de mitad de oficios hacían valer determinadas artimañas y excusas para no establecer o demorar el establecimiento de esta institución, llegando incluso a hacer nula la actividad y lo obtenido por el estado que propugnaba el establecimiento de esta institución en sus concejos.

\section{ABSTRACT}

In the 15th and 16th centuries, cohesive groups of citizens with a common cause made a request, a demand or, frequently, entered into litigation to penetrate municipal institutions, as occurred in Madridejos and other towns. This paper studies the institution of mitad de oficios or half of trades. A defence is made of the fact that it was a matter of public Law and not of the nobility. The parameters given to define it encompass the institution as a whole: as an electoral factor; as part of the framework of Castilian councils; and as a right claimed by the nobility, mostly, but also by commoners, whether they were old Christians or new, farmers or caballeros villanos, rich or poor. The paper also shows how difficult it often was to attain the desired aim, and how those who were defeated in half of trade litigation used tricks and excuses that prevented the institution from being established, or, at least, delayed it. They even managed to annul its activity completely, as well as anything obtained by the state that advocated the institution in its councils.

* UNED (C.A. de Motril). 
PALABRAS CLAVE

Corona de Castilla; Real Chancillería de Granada; concejos; Mitad de oficios en concejos; siglos XV y XVI; nobles; pecheros; caballeros villanos; conflictos sociales.
KEYWORDS

Crown of Castile; Real Chancillería of Granada; Councils; Half of trades in councils; $15^{\text {th }}$ and $16^{\text {th }}$ centuries; Nobles; Commoners; Caballeros villanos; Social conflict.

Las diferentes vías establecidas para la elección de oficiales locales en la Corona de Castilla, para la Baja Edad Media y para la Edad Moderna, son conocidas y han sido analizadas tanto otorgándoles la característica de objeto principal como la de secundario en muchos y diferentes trabajos de diversa naturaleza: historia institucional y del Derecho, historia social y nobiliaria, historia regional y local, etc. Obras sobre temas muy concretos y singulares y obras de corte general, recogen y explican en sus páginas la existencia y forma, así como preferentemente su corrupción, de los métodos que cada lugar, villa o ciudad tenía establecidos para designar a los oficiales de cada uno de esos concejos y también para modificar la estructura de estos últimos ${ }^{1}$.

Cabildos de regidores, la aparente desaparición de los alcaldes ordinarios, su sustitución -con competencias de núcleo común pero muy acrecentadas sin olvidar por lo general el nombramiento externo a la localidad- digo su sustitución por corregidores, alcaldes mayores, gobernadores, etc., la perpetuación de los oficios concejiles - presentada como realidad casi absoluta y prácticamente inamovible, no sometida a la historicidad-, pero a su vez y en cierta contradicción con lo anterior, también, los conflictos electorales, ruedas y una inmensa gama de distintas tipologías electorales, incluida dentro de ésta la llamada mitad de oficios, son protagonistas de las labores historiográficas.

Ante esto cabe pensar en casi la superfluidad de un nuevo acercamiento al tema, pero también se debe plantear una pregunta: ¿poseemos toda la luz o se necesita indagar más?

La misma realización de este análisis indica que, a mi juicio, la segunda cuestión es la adecuada dentro de esta interrogación. La realidad municipal —con sus patrones globales más o menos fijos- es muy rica, rica en número y en evolución temporal, de ahí que aborde, acotando, una realidad que es tanto medio electoral como estructural en muchos municipios de Castilla y su Corona, no eternamente, según momentos y circunstancias. Me refiero a la llamada mitad de oficios.

1 El presente artículo debe mucho tanto en documentación, como en cuestiones de fondo a mi tesis doctoral titulada Litigios de poder en concejos de la Real Chancillería de Granada: pecheros e hidalgos. La mitad de oficios en los siglos XV y XVI, dirigida por el prof. Dr. D. Blas Casado Quintanilla y que fue defendida en el año 2005 en la Facultad de Geografía e Historia de la UNED, ante un tribunal presidido por el prof. Dr. D. Carlos Martínez Shaw, y que tuvo como secretario al prof. Dr. D. Enrique Cantera Montenegro. Tesis que obtuvo la calificación de sobresaliente cum laude y a la que se le otorgó un premio extraordinario por la citada Universidad Nacional de Educación a Distancia. 


\section{LA MITAD DE OFICIOS: MADRIDEJOS A FINALES DEL SIGLO XV}

Antes de ofrecer una definición y algunas especificaciones sobre esta institución, y todo ello en relación con lo ya dicho por la historiografía, presentemos circunstancias acontecidas a fines del siglo $\mathrm{XV}$ y que poseen cualidades suficientes como para servir de ejemplo a este discurso.

Comenzaremos por la toledana villa de Madridejos, cuando menos desde 1490 la situación social en esta localidad no era todo lo apacible que podía serlo. Grupos sociales con cierta cohesión y relevancia socio-económica pretendían acceder al concejo. Grupos motivados por una comunaleza que comenzaba a extenderse por los territorios de las Órdenes Militares y sobre todo en sus grandes villas y ciudades - fundamentándose en normativas y capítulos propios de esas instituciones que amparaban a esos grupos, hasta entonces exclusos de los concejos.

Siendo Madridejos localidad de la Orden de San Juan y no llegadas las conversaciones y pleitos a compromiso alguno entre los labradores cristianoviejos que cada año ocupaban las varas de los oficios más importantes del concejo, y los hidalgos - ese era el grupo opositor y que pretendía ser admitido en el concejo, para convertirse así en verdaderos vecinos según la doctrina de aquellos tiempos-, en consecuencia los hidalgos recurrieron ante las instituciones jurisdiccionales de la Orden, en concreto a su más alta jerarquía, el prior, que estando en Alcázar, sin demasiada celeridad comisionó a un servidor suyo para que en su nombre dirimiese la contienda, fue el día 9 de enero de $1497^{2}$. No obstante debió parecer a unos y a otros que llegaba a fin esta historia o que se iniciaba su fin, pues el primer poder a procuradores de los hidalgos data de 12 de junio de 1493, poder otorgado por los hidalgos Fernand López de Cervantes, hijo de Diego López de Cervantes, Diego Vázquez, Alfonso de Mayorga, Juan del Fryo y Alfonso Pérez de Taguada.

No había acuerdo posible y González de Cuellar había ido a Madridejos como juez comisionado que debería resolver un litigio no habiendo avenencia.

Presentando nuevo poder, de 6 de enero de 1497, ante Cuellar y ante el procurador del concejo y hombres buenos del lugar Cristóbal de Mora, el hidalgo y vecino García de Cogollos, en su nombre y por los demás de su estado, solicitaba justicia.

Muy virtuoso señor, el liçençiado Antonio de Cuellar, juez comisario dado por el muy magnífico señor el prior de Sant Juan, nuestro señor, yo Garçía de Co-

2 «Mandamos a vos el liçençiado Antón Gonçález de Cuellar, del nuestro Consejo, que por quanto los honbres fijosdalgo, vesinos de Madridejos, trahen çierto pleyto con los vesinos pecheros del dicho lugar, sobre razón de los ofiçios del alcaldya e regimiento...», Archivo de la Real Chancillería de Granada (ARChG), Caja 5027, pz. 18. Dado que todo el material que se refleja en este epígrafe, correspondiente a Madridejos, responde a la signatura que se acaba de referir omitiré en adelante la misma, por innecesaria y reiterativa, pero exclusivamente en este apartado. Por el contrario se seguirán referenciando todas aquellas que no pertenezcan a esta ejecutoria de 1497 de Madridejos. 
gollos, vesino de Madridejos, lugar de esta Horden y Baylía de Sant Juan, por my y en nonbre / e así como procurador que soy de los otros omes fijosdalgo del dicho lugar de Madridejos, convyene a saber Fernand López de Çervantes y Lope Yañes e Diego López de Çervantes e Mayorga e Taguada e Diego Vasques e de los otros fidalgos del dicho lugar de Madridejos, del / poder de los quales ante todas cosas hago presentaçión, e en el dicho nonbre paresco ante vuestra merçed e propongo demanda e demando a los alcaldes, regydores, ofiçiales del Conçejo de la dicha villa, que son omes buenos pecheros. E digo que ansy es que yo e los dichos / mis partes les avemos requerido por muchas vezes nos den parte de los ofiçios del dicho conçejo, asy como alcaldyas, regimientos e fieldades e los otros ofiçios del dicho conçejo, pues entre nosotros los dichos fidalgos ay personas ábyles e perteneçientes para usar / e exerçer los dichos ofiçios o parte de ellos segund e como en las otras villas e logares de los reynos de los reyes nuestro señores. Los quales nunca han querido nin quieren darnos la dicha parte de ofiçios. Porque en los dichos nonbres pido e suplico a vuestra merçed conpela e apremie por todo rigor de Derecho a los susodichos a que realmente nos den la mitad de los dichos ofiçios o la parte que de Derecho se requiere. Para lo qual e más conplidero y en lo neçesario el noble ofiçio de vuestra merçed ynploro y en todo pido sernos fecho entero conplimiento de justiçia y en las costas fechas e las por fazer protesto ${ }^{3}$.

El concejo no demoró su escrito de contestación a la demanda. El 17 de enero de 1497 se entregaba al tribunal ${ }^{4}$. Quedaba entablado, así, un verdadero pleito ante el comisionado del prior de San Juan. Estos fueron los principales argumentos establecidos por los del lugar de Madridejos, su concejo y hombres buenos pecheros, para negar la demanda hidalga:

1. El concejo, justicia y regidores del lugar de Madridejos reconoce la antigüedad de la demanda de los que se decían hidalgos y que lo pedido había sido solicitado, su entrada en concejo, repetidamente, a lo que por otra parte admitieron siempre haberse negado.

2. Los pecheros encarnados en la institución municipal defienden ante González de Cuellar la falta de capacidad de los hidalgos para ser parte en esta demanda en concreto, no reconociéndoles derecho alguno pues afirmaron que no los tenían ni los habían tenido nunca por hidalgos, sino por pecheros y empadronados con los demás. En virtud de ello no los consideraban por parte legítima, salvo «que algunos de las partes contrarias mostrasen e provasen sus hydalguías ante quien e como devyesen».

3. Que, aunque fuesen hidalgos como ellos decían y lo probaran, no sería admisible el derecho alegado, pues era inexistente dado que la costumbre inmemorial del lugar no era otra que los oficiales salientes, encargadas sus conciencias so juramento, designasen a los nuevos alcaldes, regidores, etc.,

${ }^{3}$ Sobre el caso de Almagro existe un detenido e interesante análisis en LÓPEZ-SALAZAR PÉREZ, J.: "Limpieza de sangre y división en estados: el municipio de Almagro durante el siglo XVI», en Studia historica, historia moderna, XII (1994), pp. 157-187. En él destaca la lucha del estado de Mercaderes (judeoconversos y descendientes de tales) por poseer oficios públicos en virtud de su condición.

${ }^{4}$ La trascripción del escrito puede verse en el apéndice documental, documento $\mathrm{n}^{\circ} 5$. 
y esto tan sólo en atención a la habilidad de los candidatos, no en atención a cualquier otro aspecto (p.e. calidades). De lo que se desprendía que, si no habían sido electos, era por falta de ella, por falta de habilidad, de cualidades.

4. Además siendo la ambición por ocupar cargos de justicia lo que motivaba el espíritu y los actos de los hidalgos, estos ya se estaban evidenciando como indignos porque - en base a la doctrina, leyes y al sentir general - la titularidad de los oficios no era dable a los que la deseaban por simple interés propio y no por servicio al cuerpo político.

5. Que el derecho que pudiesen alegar los hidalgos, de existir, había prescrito por falta de su ejercicio.

6. Defectos de forma y claridad en el escrito de demanda.

7. Que la costumbre general - tanto en el priorato como en el resto de la Corona castellana - que los hidalgos pretendían ser cierta y consistente en su acceso a cargos de gobierno y justicia, era falsa y que de no serla sólo ocurriría en los medianos y grandes centros urbanos, en villas con mero y mixto imperio, pero no en lugares y aldeas donde o la jurisdicción de la que eran titulares era inferior a la mencionada o era directamente dependiente de una localidad de rango jurisdiccional superior, como era el caso por entonces de Madridejos con respecto a Consuegra.

8. Que no habiendo habido nunca debates sobre este asunto en la cabeza de partido (Consuegra) era impertinente establecer semejante discusión en una pedanía suya, más cuando en Consuegra existía alcalde ordinario por el estado de los Hijosdalgo y como tal alcalde ordinario de Consuegra, éste, poseía cierta jurisdicción sobre Madridejos, por lo que los hidalgos del lugar ya tenían representación suficiente en su émulo de Consuegra y no era conveniente ni deseable más.

9. Finalizaron su contestación a la demanda, los pecheros y su concejo, con una interesada, velada y taimada humildad: argumentaron que siendo Madridejos una aldea era impropio e indigno de la nobleza de los hidalgos ocupar cargos en el cabildo, pues, éstos, siendo tan humildes debían ser ocupados en exclusiva por los pecheros.

Al fin se iniciaban las acciones que determinarían la composición del municipio y la forma electoral del mismo, pero los pleitos suelen y solían ser largos e inciertos.

Los hidalgos no pocos, establecieron la argumentación ante el comisario del prior de San Juan. 


\section{HIDALGOS QUE SOLICITARON SU ENTRADA EN EL CONCEJO DE MADRIDEJOS EN 1497}

\begin{tabular}{|l|l|}
\hline García de Cogollos & Lope Yáñez \\
\hline Diego Vázquez & Mayorga \\
\hline Fernán López & Diego López de Cervantes \\
\hline Juan López & Taguada \\
\hline Fernán Ramiro & Ramiro de Lopiañez \\
\hline Diego López, hijo de Fernán López & Quirós \\
\hline Andrés López, hijo de Alonso López & Fernán López, hijo de Alonso López \\
\hline Fernando de Mendaño & Fernando, de Lope López \\
\hline Fernando, de Pero López & Juan Arias de Monde \\
\hline Carrasco & Juan Navalón \\
\hline Navalón, el viejo & Juan del Oyo \\
\hline & Nicolás del Oyo \\
\hline
\end{tabular}

En primer lugar se dieron y declararon por hidalgos, hidalgos que además nunca habían abandonado voluntariamente sus prerrogativas, allanándose ante las presiones del concejo pechero:

Somos fidalgos e por tales somos avidos e tenidos e en tal posysyón estamos. Y el conçejo de Madridejos no tiene un padrón alguno de nosotros como a pecheros e puesto que los tovieses, que no afirmo, sería contra razón e justiçia y Derecho e de poco tienpo acá. E por razón del tal padrón alguno de mis partes ni yo no avemos pagado nin dado pecho nin prenda voluntariamente.

Por otra parte aseguraron que más que costumbre electoral, la alegada por el concejo y los labradores, era ésta corruptela y de tal habría que tratarla, como era elegirse unos a otros, por lo que más que basamento de cualquier defensa era fundamento para la persecución y desaparición de la tal práctica.

En último lugar - dentro del escrito hidalgo- defendieron que la existencia de un alcalde hijosdalgo en Consuegra, no era argumento: pues éste conocía de los asuntos de Madridejos raramente y que, cuando lo hacía, era en apelación no en primera instancia, por lo que era conveniente que desde el inicio de la impartición de justicia y del ejercicio del gobierno hubiese hidalgos en el concejo, hidalgos y no hidalgo como en Consuegra, donde si sólo tenían una alcaldía era por negligencia, es decir que era necesaria la mitad de oficios, más cuando lo esencial para ésta no era que la localidad fuese mayor o menor, sino que en todas partes resplandeciese la justicia: 
Porque para governar el pueblo e exerçer bien la justiçia, en lo que a ellos toca, nos deve ser dada la otra parte, no puniendo dyferençia en ser lugar o villa, porque para governar el pueblo e exerçer bien la justiçia non deve ser suelto nin sugevto, porque cada uno tiene su juridiçión e regimiento.

Los pecheros seguían negándose, correspondía decidir en exclusiva a González de Cuellar, no habría convenio entre las partes. Porque para los labradores villanos - no debía existir en realidad padrón en que constasen los hidalgos por pecheros - todos aquellos que querían el poder en realidad habían sido exentos por influencias no por noblezas, "por hallegados e paniaguados de cavalleros e de otras personas poderosas, más no por ser tales fidalgos».

Había, según los villanos, tan pocos hidalgos que sería perpetuar en sus manos los oficios, sin olvidar que no era corruptela lo existente en Madridejos y que ésta era costumbre tan notoria que no hacía falta ni demostrarla, y además que era costumbre extendida por gran parte de la Corona, sin que existieran esos oficios para nobles, oficios tan perjudiciales al común, al estado Llano Pechero, y más aún en el lugar de Madridejos, pues ya había alcalde noble en la cabeza de partido y de existir más, todo sería perdido:

Sería destruyr a los labradores e todo el cuerpo de la república, disminuyr los pechos y tributos reales que solamente los pagan los labradores... E asy digo que non deven de ser admitidos a la dicha alcaldía, nin a los otros ofiçios. E pues que son poblados al fuero de Consuegra, quando alguno ofiçio se le oviese de dar sería contra justiçia e con grand cargo de conçençia, avría de ser segund la calidad e uso e costumbre de la villa de Consuegra, donde son subgetos, que en quanto a esto son avidos por una universidad.

Negaban así, los pecheros, el todo — la entrada de nobles en el concejo- pero también la parte, no poco esencial —la mitad de oficios-ya que si algo habría que otorgar sería como mucho una alcaldía, al estilo de Consuegra.

Ante que la mayoría de las ciudades, villas y lugares del entorno de Madridejos -fuesen de realengo, señoríos o perteneciesen a alguna Orden Militar-comenzaban a poseer hidalgos en sus cabildos y, lo que es más, conocedor el concejo de que leyes capitulares y ordenanzas de las Órdenes Militares - aquí en concreto Calatrava y San Juan- prescribían la entrada en estas instituciones de los estados de Hijosdalgo y de Mercaderes - como hemos dicho descendientes de conversos de judíos- sopesaron la muy segura posibilidad de que el comisionado del prior de San Juan terminara si no ordenando la mitad de oficios, sí sentenciando de algún modo que los nobles fueran parte de la institución municipal. La sospecha podía convertirse en realidad, así que qué mejor que no fuera la Orden de San Juan y en su nombre González de Cuellar quien sentenciase. Había una oportunidad, otro hidalgo llamado Juan Díaz, harto de no ser escuchado por los pecheros había recurrido directamente a la Chancillería de Ciudad Real, así que los labradores villanos negaron la capacidad jurisdiccional de Cuellar y de la Orden porque la mismísima Corte y Chancillería del Rey había atraído para sí el caso, siendo por 
tanto la única jurisdicción que debía entender —ante un conflicto de competencias- la Audiencia de Ciudad Real5.

Buen intento, pero fallido, pues el juez comisionado no sólo no aceptó inhibirse sino que amenazó a la parte villana, en concreto a quien había sugerido tal posibilidad, el antiguo procurador Cristóbal de Mora:

No sabe lo que se dize, que él puede conoçer de la dicha cavsa e de otras qualesquier y pues que le consta que lo dixo por ynjuriar al dicho juez y pues él no puede ser avydo para ser castigado corporalmente, que mandava e mandó al dicho Juan Marín, procurador del dicho conçejo que mire y alegue de su justiçia porque de otra manera le castigará sy más dixere.

Ante su autoafirmación como juez legítimo y su decisión de proseguir el conocimiento de la causa, ésta entró en fase de prueba, ambas partes iniciaron las diligencias de sus probanzas, inclusive los pecheros que ante las amenazas y actitud de Cuellar no se apartaron del todo del litigio.

El 23 febrero de 1497 las iniciaron los hidalgos, en busca de la demostración de su derecho centrado en tres cuestiones principales que buscaron corroborar por

${ }^{5}$ Las Órdenes Militares desde la segunda mitad del siglo XV propugnaron de hecho y de Derecho, la entrada - no exactamente la mitad de los oficios- de los estados de Mercaderes e Hidalgos en los concejos. Eso era comúnmente sabido, pero no era obstáculo para no cumplirlo en cuanto se pudiese, por ejemplo Manzanares había acatado esto en los siglos XV y XVI, pero no siempre. En 1529, estando en Almagro frey Tello Ramírez de Guzmán, comendador de Moratalaz, gobernador y justiçia mayor de las villas y lugares del Campo de Calatrava, concretamente el día 16 de septiembre de 1529 se presentaron ante él Bartolomé de Fontiveros, Rodrigo de Villaescusa, Juan de Porras y Alonso Hernández, vecinos de Manzanares por sí y en nombre de los hijosdalgo y mercaderes de Manzanares diciendo que: «estando estatuydo y hordenado asy por hordenanças de esta provinçia, confirmadas e aprovadas por los Católicos Reyes don Fernando e doña Ysabel, nuestros señores que ayan gloria, como por abtos capitulares de esta Horden, que las alcaldías e regimientos e los otros cargos e ofiçios públicos del conçejo se den en la dicha villa y en los otros pueblos de esta provinçia a las personas ábiles e sufiçientes que obiere, asy del estado de los Hijosdalgo e cavalleros y mercaderes como labradores, discurriendo por el padrón de la villa syn cabtar ningunas personas, para que todos ygualmente gozen de los dichos cargos e ofiçios e la justiçia sea mejor administrada, e aviéndose asy usado e guardado en esta provinçia como es notorio, los alcaldes e regidores de la dicha villa de dos años a esta parte, en las eleçiones que se an hecho de los dichos cargos, con cabtelas e parçialidades que entre ellos a avido, an tenido manera de escluir a los hijosdalgo e mercaderes, porque las alcaldías e regimientos estén y anden entre labradores e parientes, acostunbrándose a elegir e tener y exerçer los dichos cargos e ofiçios los hijosdalgo e mercaderes. Lo qual a resultado en perjuiçio nuestro y en gran daño de la república de la dicha villa. Por razón de lo qual a nuestra suplicaçión e pedimiento Su Magestad a proveydo e mandado que la helezión que se a de hazer en la dicha villa por el día de San Miguel de setienbre no se haga sin que vuestra merçed esté presente para que todos los ábiles entren en suertes, syn distinçión de partidos ni inçibtaçión de personas, e se escusen los fraudes e cabtelas que en las dos heleçiones pasadas an tenido como consta por esta probisyón que presentamos. Por tanto a vuestra merçed suplicamos cunpla lo que Su Magestad manda. Y cunpliéndolo vaya o enbíe a la dicha villa un letrado, persona de çiençia e conçiençia que haga la dicha eleçión conforme a las dichas hordenanças, abtos capitulares de esta Horden y discurriendo por el padrón entren e metan en suertes todas las personas ábiles e sufiçientes que oviere para tener, usar y exerçer los dichos ofiçios e cargos, asy del estado de Hijosdalgo e Mercaderes como de los Labradores e no permita ni dé lugar a que se haga ni intervenga en la dicha eleçión ningún fraude ni cabtela. Guardando las dichas hordenanças como Su Magestad lo manda... e a la persona que fuere mande que lleve vara de justiçia con facultad e poder de traer alguazil para proçeder y prender a los que fueren culpantes". Frey Tello Ramírez de Guzmán comisionó el 29 de septiembre de 1529 al bachiller Lucas de Villanueva para que realizara las elecciones. Pero no fue la última vez que en Manzanares los estados no labradores quedaron excluidos del concejo. ARChG, Hidalguía, Caja 820, pz. 5. 
medio de los testimonios que tanto de pecheros como de hidalgos, la mayoría vecinos de Consuegra y otras localidades, presentaron:

1. Su condición hidalga y el número suficiente que de estos moradores existía, desde cuando menos diez años acá, en Madridejos, en tal forma que no quedarían los oficios en manos de unos pocos: «que crehe que hay más fidalgos en el dicho lugar Madridejos que en ninguna aldea de toda la Horden». No obstante los testigos dudaron en el origen de las exenciones de algunos de ellos, si eran por nobleza o por otra causa: así ocurre con García de Cogollos, que a la sazón era aposentador del actual prior, o con Alonso de Taguada, que era hijo del que fuera montero mayor de un prior de San Juan. Así la duda esparcida era, no otra, que si eran excusados por nobles o por criados cercanos a la cabeza de la Orden de San Juan, si bien es cierto que son los únicos casos en que esta duda recae sobre las partes hidalgas.

2. Que lo exigido era realidad y costumbre ya asentada tanto en zona sanjuanista como de las otras Órdenes, por ejemplo en Villarrubia de Calatrava (hoy de los Ojos) había alcalde ordinario hidalgo o que «en la villa de Consuegra y en la villa de Alcáçar ay un alcalde fidalgo y otro labrador y en las otras villas e lugares de la baylía que no lo sabe»; «que en Consuegra de mucho tienpo acá e en Alcáçar de poco tienpo acá ay alcaldes fidalgos juntamente con los labradores".

3. El último fundamento era netamente político: la incapacidad y corruptela de los concejos hasta entonces de pecheros, pues los labradores, la mayoría iletrados, no tenían aquellos oficios «por honra e por provecho que de ello les sygue, salvo por tener el mando del pueblo», en tal manera que «a la dézyma pregunta dixo este testigo, que sabe que los dichos ofiçios nunca salen de entre hermanos y parientes y que nunca miran sy son ábyles nin sufiçientes para tener los dichos ofiçios, salvo porque son parientes e por yntereses que en ello les va».

Los labradores sabían que la Orden no les sería favorable, de modo que esta vez el procurador Marín solicitó nuevamente, el 1 de marzo de 1497, que González de Cuellar se apartase y dejara a los legítimos y naturales jueces, los de la Chancillería de Ciudad Real, que conocieran, pues allí se seguía igualmente el mismo pleito. No fue esto lo que hizo Cuellar ni su Orden: el primero marchó de Madridejos por mandatos superiores, pero de inmediato el prior comisionó ahora a Hernando de Benavente, juez de residencia, alcalde y justicia mayor nombrado para Consuegra, Alcázar y las demás localidades de la bailía. Esto acontecía el 28 de julio de 1497. El concejo se apartó del litigio, manteniendo su defensa sólo ante Ciudad Real y sus jueces, el 28 de septiembre de ese año García de Cogollos hacía su último requerimiento y solicitaba la declaración de rebeldía de los pecheros.

Reflexionando, el 16 de octubre de 1497, ya no Marín sino el que fuera desaparecido procurador villano Cristóbal de Mora, se presentó ante Benavente y solicito la restitución, cosa que le fue concedida en el mismo acto. 
Probanzas y más probanzas, los hidalgos seguían sosteniendo con realidades la expansión de este fenómeno concejil, en Lora y Castronuño, en el último caso desde hacía 16 años, los oficios rondaban entre hidalgos y labradores. Villarta, Herencia y Arenas de San Juan igualmente tenían alcaldes hidalgos, pues además en cualquier lugar -fuere de la categoría que fuese- los oficios eran de honra y dignos de hidalgos.

Los pecheros no podían seguir negando las evidencias, por todos conocidas y por el juez Benavente también, por lo que recurrieron fundamentalmente a afirmar que la entrada de los exentos, de estos hidalgos, arruinaría la república de Madridejos, como había sucedido en otros lugares, y, lo que era más grave, que todo ello estaba en contra del derecho adquirido por el uso y costumbre inveterada y nunca incumplida que establecía la pechería del concejo, costumbre válida y que no podía ser modificada por una simple sentencia de un juez comisionado:

Nunca lo oyó deçir a los antepasados, que los fidalgos usasen de tal ofiçios en el dicho lugar Madridejos.

La ejecutoria está incompleta, seguramente se dio a los hidalgos cuando menos la alcaldía o quizá no, pues el 14 de julio de 1527, unos treinta años después de las actuaciones hasta ahora vistas, los hidalgos de Madridejos, no pudiéndolo hacer en su localidad por diversas presiones, dieron en Alcázar de San Juan nuevo poder a los procuradores Gastón de Caicedo y Fernando de Córdoba: esto ocurrió el 14 de julio de 1527.

Que nosotros tratamos ante Sus Magestades en la su Abdençia Real, que reside en la grand çibdad de Granada, con los buenos omes pecheros del dicho logar Madridejos, sobre razón de las alcaldías e regimientos que les pedimos e sobre otro pleito que nos movieron para que pagásemos çierto repartimiento ${ }^{6}$.

\section{HIDALGOS DE MADRIDEJOS QUE DIERON SU PODER EN ALCÁZAR DE SAN JUAN EN 1527}

\begin{tabular}{|l|l|}
\hline Fernán Ramírez, diputado nombrado por los hidalgos & Juan Díaz de Lupiañez \\
\hline Diego Remón & Lopiañez \\
\hline Arias de Taguada & Francisco Lorencio \\
\hline Diego López de Lupiáñez & Fernán López de Lupiañez \\
\hline Alonso Gallego & Juan Díaz (hermano de Gallego) \\
\hline Diego López de Alonso López & Fernán López de Alonso López \\
\hline Fernán Páez & Juan Remón \\
\hline Juan de Bolaños & Alonso de Mayorga, el mozo \\
\hline
\end{tabular}

${ }^{6}$ ARChG, Caja 2633, pz. 7.

7 Pertenecían ambos hermanos a la familia hidalga de Villlarrubia de los Ojos del Guadiana llamada Díaz-Hidalgo, como se decanta en mi artículo «Linajes nobles de Villarrubia de los Ojos del Guadiana en el siglo XVI y la Real Chancillería de Granada», en Cuadernos de Investigación Genealógica, número extraordinario (1999), pp. 143-163. 


\section{MADRIDEJOS, A MODO DE EXCUSA}

Pleito de mitad de oficios y repartimiento, acción y reacción. Solicitud para ingresar en el concejo, negación y repartimiento y todo tipo de argumentos y vejaciones para constreñir a los solicitantes a retirar sus pretensiones ${ }^{8}$.

Lo cierto es que en la frontera de los siglos XV y XVI muchas localidades al sur del Tajo comenzaban a sufrir las presiones de quienes se decían hidalgos para ser parte de las instituciones municipales. De forma legítima o ilegítima, en cuanto a nobleza y orígenes, la realidad era que se iban conformando grupos - quizá ya más liberados de sus relaciones feudovasalláticas, que estaban en declive y por tanto necesitados de un puesto en el nuevo orden social- que veían aspectos muy interesantes en las actuaciones y jurisdicciones concejiles, hasta entonces mayoritariamente pecheras en las poblaciones medianas y pequeñas del territorio que sería con el tiempo el de la Chancillería de Granada, y aún en algunas localidades de relieve -Almagro por ejemplo9.

8 Una buena medida, aunque muy costosa, era denunciar ante Granada a todo el conjunto de personas que se decían hidalgos - lo fuesen o no y se supiese o no. Medida que a veces pudo ser fraude establecido por los que querían ser nobles, que a través del concejo que dominaban se autodenunciaban pues pretendían así terminar con ejecutorias de hidalguía dadas por Granada — sinceramente creo que serían, pese a lo alegado en los tribunales y por la historiografía, sólo casos muy concretos- pero otras muchas veces, es también evidente, que era la forma que los poderosos de origen pechero elegían para molestar y dividir el estado de los Hijosdalgo — siempre habría quien no pudiese seguir pleitos o siguiéndolos los perdiesen-, ataque por tanto pechero que podía darse por motivo de un intento de implantación de la mitad de oficios o por luchas políticas posteriores una vez implantada ésta. Sucede en Consuegra por ejemplo y como muestra la siguiente delación al fiscal de Granada con los nombres de los que se decían hijosdalgo y eran denunciados - si se compara con Madridejos hay coincidencias de nombres y linajes: «En la çibdad de Granada, diez y ocho días del mes de junio de mil y quinientos y ochenta y quatro años, ante mí el escrivano y testigos de yuso escriptos, paresçió presente Gerónymo de Torres, procurador y vezino de esta çibdad en nonbre de los contenidos en el requerimiento y me pidió y requirió con este escrito de delaçión y requerimiento firmado de su nonbre, del thenor syguiente y pidió lo notificase al muy ilustre señor liçençiado Diego de Ameçaga, fiscal de Su Magestad, que estava presente y lo pidió por testimonio, syendo presentes por testigos Grabiel de Martrato y Pedro de Oleçaga y Gonzalo de Múxica, veçinos y estantes en Granada. / Escrivano presente dadme por testimonio en manera que haga fe a mí Gerónymo de Torres, procurador en esta Real Audienzia y vezino de Granada, e nonbre de Miguel Pérez de la Ronda y Juan Rodríguez Crespo, vezinos de la villa de Consuegra, y por virtud del poder que de ellos tengo, cómo digo y requiero y hago saber y delaçión al muy ilustre señor liçençiado Diego de Ameçaga, fiscal de Su Magestad en esta Corte e Chanzillería de Granada y digo que Pedro de de Arze, hijo de Diego de Arze, y Franzisco de Arze su hermano; y Alonso Remón, hijo de Franzisco Remón, y Guillén Remón su hijo, y Guillén Remón hijo de Diego Remón; Juan Gallego, hijo de Rodrigo Gallego, Rodrigo Gallego, su hijo, Alonso Gallego, hijo de Juan Gallego, Gómez Gallego su hermano, Alonso Gallego, el viejo; Rodrigo de Sarriá, hijo de Estevan de Sarriá, Juan de Sarriá, / su hermano, Sebastián de Sarriá, su hermano, Estevan de Sarriá, su hermano, Bernavé de Sarriá, su nieto; Juan de Madrid, hijo de Andrés de Madrid, Andrés de Madrid su hijo, Franzisco de Madrid su hermano, Alonso de Madrid, hijo de Juan de Madrid, Fernando de Madrid su hermano, Antonio de Madrid, hijo de Antonio de Madrid, Diego de Madrid su hermano; Balmaseda, yerno de Pero López; Diego de Madrid, hijo de Franzisco de Madrid, Alonso de Madrid su hermano, Juan de Madrid, hijo de Andrés de Madrid, Fernando de Madrid hijo de Miguel de Madrid, Cristóval de Madrid su hermano; Juan de Leguizamo, Cristóval de Taboada su yerno; Alonso López de Çervantes, yerno de Juan Alonso, tendero, Juan López de Çerbantes...» ARChG, Hidalguía, Caja 4943, pz. 13.

9 Sobre la zona de las Órdenes Militares cabe, junto al trabajo de López-Salazar sobre Almagro ya citado, destacar los trabajos GUERRERO MAYLLO, A. «Hidalgos y pecheros en el antiguo reino de Toledo. La «mitad de oficios» concejiles en la comarca de Quintanar (Siglos XVI-XVII», en Anales Tole- 
Grupos en su mayoría cohesionados quizá, más que por ser todos sus componentes de la misma calidad - aquí y por el momento nobles_-, porque estaban unidos por los ataques que sufrían de sus concejos, por la exclusión sufrida ante un común labrador y pechero que hasta entonces poseía el poder municipal y que teóricamente tenía intereses distintos y en mucho opuestos.

Sepades que por parte de los cavalleros e fydalgos, veçinos de Villanueva, nos fue fecha relaçión, etc., dyziendo que los hofyçios de alcaldes e regydores e otros ofyçios públycos de la dicha villa, se reparten entre sy los labradores e omes buenos pecheros de ella. $\mathrm{E}$ que a los dichos cavalleros e ydalgos non dan ni se reparten ningunos de los dichos ofyçios... nos fue suplycado e pedydo por merçed que sobre ello les proveyésemos de remedio con justyçia, mandando que los dichos ofyçios de alcaldes e regydores e los otros ofyçios públicos de la dicha villa se repartyesen en cada un año entre todos los cavalleros e ydalgos e pecheros $^{10}$.

Por lo que se refiere al presente artículo y por lo habitual eran los nobles los que solicitaban entrar en cabildo, pero no son ni fueron los únicos: cristianos viejos frente a nuevos, nuevos frente a viejos; pecheros frente a hidalgos; o cuantiosos frente a pecheros o viceversa ${ }^{11}$.

danos, 25 (19888), pp. 81-93. Y, también, GONZÁLEZ DE SAN SEGUNDO, M.A.: «Notas sobre la distinción de estados y la mitad de oficios concejiles en los siglos XVI y XVII (El caso del Espinar)", en $\mathrm{Hi}$ dalguía, 31 (1983), pp. 549-559.

10 Archivo General de Simancas (AGS), Registro General del Sello, 1496 abril, fol. 127. El Registro del Sello de Simancas da más de una muestra de estas peticiones de entrada de los nobles en concejos.

${ }_{11}$ Cristianos viejos frente a nuevos como sucedería en Abanilla -localidad estudiada entre otros por Torres Fontes y Sáez Sánchez, TORRES FONTES, J.: El señorío de Abanilla. Murcia, Patronato de Cultura de la Diputación, 1962 (la primera edición). SÁEZ SÁNCHEZ, E.: «Ordenanzas de la aljama de Abanilla», en Anuario de Historia del derecho español, 14 (1993), pp. 519-529._- En Abanilla en 1583 decían los cristianos viejos: «Cristóbal Pérez en nonbre de Pero Martínez y Juan Pérez e Luis Garçía de Mendoza e otros sus consortes, de quien tengo poder, vezinos de la villa de la Avanilla, cristianos viejos, digo: estando los dichos mis partes y otros vezinos cristianos viejos de la dicha villa en posesión de ser elegidos a los ofiçios de alcaldes e regidores e alguaziles de la dicha villa o a lo menos de la mitad de los dichos ofiçios, de seis años a esta parte los vezinos moriscos, deszendientes de moros, vezinos de ella, se an alzado con todos los dichos ofiçios. Elijiendo unos a otros, e padres a hijos, e parientes a parientes. Todo a fin de escluir a los cristianos viejos", Archivo Histórico Nacional(AHN), Órdenes Militares (OOMM), Archivo Histórico de Toledo, $n^{\circ} 40124$. Como ejemplo de pecheros contra hidalgos, entre muchos sirva la ciudad de Ciudad Real, cuando en la década de los treinta del siglo XVI se quejaban los pecheros de que los nobles le habían arrebatado la alcaldía correspondiente al estado de los Ciudadanos, estado maliciosamente llamado por los hidalgos "de labradores y mercaderes», así en 1537 Diego de Arroya, en nombre de Melchor de las Higueras y de los demás ciudadanos, solicitaba se confirmase la sentencia del teniente de corregidor Dávalos por la Chancillería de Granada, porque «por leyes de vuestros reynos las alcaldías de la Hermandad y todos los otros ofiçios se an de repartir entre los hijosdalgo y los pecheros y así está mandado por las provisiones del señor Rey don Juan, predeçesor de gloriosa memoria, de quien Vuestra Magestad depende, y confirmado por el uso y costunbre antigua de la Çibdad Real», ARChG, Hidalguía, Caja 4982, pz.13. Por último, cuantiosos contra pecheros o viceversa, como ocurrió en Mengíbar donde los cuantiosos reclamaban en exclusiva para sí los oficios y no sólo la mitad de ellos que compartían con los otros pecheros no caballeros pues «el uso e costunbre del dicho lugar e de los otros logares de la tierra e juridisçión de esa dicha çibdad çerca del poner ellos ofiçiales e jurados e mayordomos, que han sydo de tienpo ynmemorial acá se eligir en cada un año, se echavan por suertes los dichos ofiçios entre los cavalleros de premiá», los cuantiosos consiguieron el amparo regio por real provisión dada en Granada en 15 de septiembre de 1499, AGS, Registro General del Sello, 1499 septiembre, fol.292. 
Lo que resulta indiscutible es que nos encontramos ante la culminación -en cada caso- de una desavenencia social que termina en conflicto abierto. Pocos debieron ser los pueblos del sur del Tajo que entregaron parte de su poder político de forma pacífica a aquellos grupos que demandaban ser considerados vecinos y no moradores ${ }^{12}$.

Lo habitual es la negación continuada ante los requerimientos y eso pese a que existan normas de naturaleza territorial que en ocasiones preceptuaran la incorporación a los concejos de estos grupos sociales hasta entonces excluidos.

Fue la nobleza la que más insistió y, también seguramente, la más protegida por las instituciones superiores para que accediera a todo tipo de organismos y aquí a los concejiles, pero no deben olvidarse las actuaciones, que deberían ser más destacadas historiográficamente, de potentes y relevantes instituciones de la Corona de Castilla que, como las Órdenes Militares, en grandes zonas de sus territorios dotaron de la facultad de acceder a concejos a grupos sociales destacadamente denigrados a través de la ideología de la pureza sanguínea, como fueron los descendientes de conversos de judío o de moro ${ }^{13}$.

Todo está encerrado en una evolución fáctica e ideológica, tanto local como a nivel de toda la Monarquía, que parte de lo concreto pretendiendo llegar a lo absoluto, y a veces, las menos, consiguiéndolo.

12 Se trataba de unir poblaciones, teóricamente, de hacer un común que viviese una paz social cotidiana dirigido por las personas más hábiles y desinteresadas. Esa teoría, alejada de la realidad pero argumentada por leyes, doctrina, letrados y partes, viene perfectamente recogida en la sentencia de 24 de enero de 1537 dada por el presidente y oidores de Granada en el pleito entre el estado de Mercaderes descendientes de conversos de judíos- y el concejo de la villa de Alcázar de San Juan. «pronunçiamos a los dichos Rodrigo Mexía y a Lope López y sus consortes por ábiles e capaçes para poder ser elegidos en todos los ofiçios de la dicha villa... e que agora e de aquí adelante tengan a los dichos mercaderes, e que son e fueren en la dicha villa, por tales e que en las eleçiones que de aquí adelante para syenpre jamás se hizieren en la dicha villa de los ofiçios de ella, amitan a los vezinos e moradores de la dicha villa así hidalgos, como labradores, como mercaderes. E que todo sea un pueblo, un cuerpo, syn aser distinçión de regimiento que hasta aquí se daba a los dichos mercaderes y del dicho pueblo nonbren para los ofiçios de la dicha villa las personas más leales e de mejor fama e más ábiles e sufiçientes que les convengan los dichos ofiçios conforme a las leyes de los reynos», ARChG, Hidalguía, Caja 820, pz. 5.

${ }_{13}$ La nobleza la más protegida, pero sin que ello implicare que la Monarquía y sus órganos principales no respetaran el Derecho y los derechos de las partes. Por ejemplo una de las cuestiones cas siempre debatidas en los pleitos de mitad de oficios concejiles era si los que pleiteaban como hidalgos su hidalguía, con objeto, después, de obtener la mitad de oficios, podían mientras existiese contienda entrar en cabildo. Las respuestas fueron variadas, como casi siempre, pero hubo una que fue la más seguida, respuesta que se puede ejemplarizar en el caso de Almodóvar del Campo cuando sobre 1555 seguía su concejo, pleitos de hidalguía contra varios hidalgos: Sancho de Villegas, Francisco Gijón el mozo, Alonso de Valdecabras, Álvaro de Torres, Pascual de Cañizares y los menores hijos de Juan Gijón y Hernando Gijón. El concejo les prohibió su entrada en él como oficiales mientras hubiese pleitos, ya que «pretendían ser hijosdalgo, los quales dichos pleitos por los susodichos entrar en suertes y ofiçios de conçejo no se avían seguido ni seguían», los hidalgos protestaron y ganaron una sentencia de la Chancillería granadina en la que se les otorgaba la razón y se la quitaba a Almodóvar y su concejo, era 30 de enero de 1555. Apelado todo al fin Almodóvar consiguió sentencia firme del presidente y oidores para que fueran apartados del concejo los hidalgos hasta la resolución de los litigios. Presidente y oidores que mandaron a los alcaldes de los Hijosdalgo y notario de la Provincia de Toledo que expidiesen una real provisión para que todo se cumpliera, provisión datada en Granada a 24 de mayo de 1557, ARChG, Hidalguía, Caja 5093, pz. 268. 
Durante el siglo XV en estos territorios de las Órdenes Militares los concejos aún son mayoritariamente pecheros, más de labradores que de caballeros, pero no sólo ocurre aquí y de este modo. Por ejemplo en la zona del marquesado de Villena, fuera de las Órdenes, los municipios siguen siendo pecheros aunque mayoritariamente allí de caballeros de cuantía, sin olvidar zonas como las andaluzas y por muestra dentro de ellas las del territorio sevillano ${ }^{14}$.

14 Por ejemplo en Alcañabate cuando los hidalgos Rodrigo Pacheco, Andrés y Juan de Alarcón, Arias de Tovar, Juan Gómez de Peralta, Juan del Campo, Bernardino López, Pedro de Lomas, Juan de Gavaldón, Martín de Laguna, Alonso de Araque, Gómez de Peralta, Juan Rabé y Diego de Castañeda solicitaron entrar en el concejo de su villa, la parte contraria alegó el 27 de septiembre de 1510 que «en la dicha villa ay costunbre usada e guardada de tienpo ynmemorial a esta parte que los omes fijosdalgo no entran en los ofiçios del dicho conçejo, ni se reçiben a ellos. E las partes contrarias se dizen omes fijosdalgo e asy non pueden ser reçebidos a los dichos ofiçios, lo qual se ha usado del dicho tienpo ynemorial a esta parte asy antes que la dicha villa de Alcañavate fuese villa como después que lo es. Lo otro porque allende de la dicha costunbre ay sentençia, la qual ha mucho tienpo que se dio, por la qual se manda que los que no pecharen en la dicha villa, tres o quatro çentenas, que no sean reçebidos a los ofiçios públicos. E las partes contrarias esymense de pechar disiendo que son hidalgos e asy non pueden ser reçebidos a los dichos ofiçios. E aunque no se esymiesen por fidalgos no tienen tantos bienes que puedan pechar las dichas tres o quatro çentenas. Lo otro porque las partes contrarias e cada uno de ellos biven con cavalleros de la comarca: los unos con el marqués de Villena e otros con Rodrigo Pacheco e Diego Pacheco e con otros cavalleros. E segund leyes e ordenanças de estos reynos, ninguno que bive con cavallero no puede tener ofiçio público del conçejo. Lo otro porque las partes contrarias no biven en la dicha villa de Alcañavate ni tienen en ella sus mugeres nin casas, antes biven en las aldeas de la dicha villa e en otras partes», ARChG, Elecciones, Caja 501, pz. 5. En definitiva un concejo de raíz pechera, que basa la posibilidad de acceder a oficios en la posición económica de sus vecinos y de sólo ellos y que repele de sí a los nobles y al entramado feudal en el que están insertos. Otro testimonio, ahora de un hidalgo juramentado de calumnia en la probanza del concejo y pecheros realizada en el pleito de mitad de oficios de Don Benito en la primera mitad del XVI: «que estando en los dichos lugares munchas vezes de tres a quatro años a esta parte, poco más o menos, que se ponen los ofiçiales del conçejo de ellas pecheros e no hidalgos, porque este testigo a visto e conoçido a los dichos ofyçiales, e a oydo dezir de tres o quatro años a esta parte, poco más o menos, a munchas personas que de sus nonbres al presente no se acuerda, públicamente que en todas las otras aldeas de la dicha çibdad de Mérida se ponen los dichos ofiçiales pecheros e no hidalgos. E asymismo a visto este testigo de siete o ocho años a esta parte estando munchas vezes en el lugar de Alcuesca y en las Casas de Don Antonio, que son aldeas de la villa de Montanches, que se ponen los ofyçiales del conçejo de ellas pecheros e no hidalgos, a los quales este testigo a visto y conoçido y son pecheros e a oydo desir en las dichas aldeas a muchas personas que de sus nonbres al presente no se acuerda, públicamente que en todas las otras aldeas de la dicha villa de Montaches se ponen los dichos ofyçiales pecheros y no hidalgos» ARChG, Hidalguía, Caja 5033, pz. 14. Para el campo sevillano (Aljarafe y Ribera sevillana), con excepciones relevantes, pero como generalidad de la pechería que sufrían sus concejos a fines de la Edad Media (s. XV) dice la Dra. Borrero Fernández: «la exención de pecha por cualquier motivo, era igualmente causa de pérdida del derecho de un vecino a ser elegido como oficial del concejo. Así, monederos, bacinadores, ballesteros de nómina, hidalgos, paniaguados de caballeros, etc., no eran elegibles». Recordemos que entonces eran oficios añales y sometidos a elección los de alcalde ordinario, regidor, mayordomo y alguacil, entre otros, Borrero Fernández, M.: El mundo rural sevillano en el siglo XV: Aljarafe y Ribera. Sevilla, Excma. Diputación de Sevilla, 1983, p. 405. Será en los años treinta del siglo XVI y en los siguientes hasta el siglo XVII, cuando el término sevillano vea surgir en casi todos sus concejos la mitad de oficios, con el estado de los Hijosdalgo como propulsor de ella. Impulso y arraigo al que no fue ajeno el concejo de Sevilla que si no como institución, sí a través de sus regidores de forma más o menos particular fomentó y fomentaron su implantación. Implantación que a veces soportó resistencias relevantes como en el caso de la villa de Guadalcanal, hoy provincia de Sevilla, pero entonces en territorio de Órdenes Militares, que en 1575 hasta llegaría a utilizar el recurso de las MIl y Quinientas Doblas en defensa de la pechería de su concejo, con lo que esto suponía de riesgo económico para el concejo y apelantes, en ARChG, Hidalguía, Caja 4994, pz. 18. 
El monopolio de instituciones tan relevantes para el cotidiano existir como los concejos por los grupos más numerosos y de entre ellos, por sus sujetos más ricos y poderosos, se traducía en el afianzamiento de la desigualdad económica pero no en una desigualdad de orígenes y calidades: existía cierta monotonía desde esa perspectiva. De ahí, junto a todas las teorías previas y posteriores, que esa uniformidad que facultaba a cualquiera que llegase a poseer bienes suficientes a poder aspirar al poder, se viera limitada paulatinamente por teorías ideológicas respaldadas por el común asentimiento a través de requisitos artificiales pero cada vez más extendidos: por ejemplo prohibiciones por dedicarse a oficios viles el ahora rico o sus pasados, etc.

Pero la sociedad gobernada por esos concejos tornábase cada vez más en una colectividad compleja. A mi parecer por dos realidades bajomedievales y sobre todo del último siglo de la Edad Media: el uno, el fin de la nobleza verdaderamente feudal ya con los Reyes Católicos y lógicamente el fin de toda la estructura y entramados e instituciones que conllevaba; el segundo, la aparición de cristianos nuevos en gran número desde el siglo XIV, no necesariamente pobres que exigen -pese a las persecuciones y quizá por eso-, digo que exigen su asimilación y su acceso como iguales a cada una y todas de las instituciones que conforman una Monarquía católica. La reacción a esto último es destacadamente conocida y estudiada, pero era evidente que el estigma de los descendientes de conversos - de judío o moro- les repele e intentan de hecho y también bajo razonamientos totalmente lógicos apartarlo de sí. Tras la guerra de las Alpujarras y en pleito de mitad de oficios con los cristianos viejos, decían los tildados de moriscos de la villa de Abanilla lo siguiente:

A la segunda pregunta dixo que save que los vezinos de esta villa desçienden de cristianos nuebos, pero que están en el quarto grado e terçero grado y los que agora son, son cristianos hijos de cristianos y sus tratos, vestidos, testamentos y toda horden de vibir son de cristianos viejos y por tales este testigo los tiene... Lo otro porque los veçinos de la dicha villa a quien las partes contrarias llaman cristianos nuebos no lo son, sino biejos por ser tan antiguos como es notorio y conforme a vuestra reales leyes son capazes como todos y ansí sienpre an tenido los dichos ofiçios ${ }^{15}$.

15 AHN, OOMM, Archivo Histórico de Toledo, № 40124. Los estados de Mercaderes, notoriamente y por todos conocidos como descendientes de judíos conversos, intentaron durante la Edad Moderna que fueran asimilados por el estado de los Labradores pues todos eran pecheros, cosa que no consiguieron mayoritariamente, por un lado por oposición de los mismos labradores cristianos viejos y por otro por el escaso apoyo de las instituciones, aunque hubo casos como en Manzanares en donde se llegó a conseguir. Caso emblemático es el de Almagro, capital de la Orden de Calatrava en donde no se consiguió, y eso que fueron llevados al rey Felipe II numerosos memoriales la mayoría a nombre de Vallo de Anaya, véase éste de 1593: «Gómez Vallo de Anaya, vezino de Almagro, pide se consuma un estado de tres que ay en la dicha villa que llaman de mercaderes y que queden dos, de ydalgos y labradores, por los yncombenientes que se siguen. Mandose que ymformase el alcalde mayor. Ynforma que por una concordia dada por don Garçí López de Padilla, maestre de Calatrava, el año de quatroçientos y ochenta y dos, mandada guardar por executorias de Granada, ay los dichos tres estados en la eleçión de los ofiçios y que le pareçe que se podría resumir en dos y quitar el de los mercaderes, por las pasiones y notas que se siguen a ello». Al margen «Sigan su justiçia». AHN, Consejos, Leg. 7053. Al final existe una consulta en donde se dice que nunca más se acepte alegato alguno sobre Almagro y este asunto. 
Grupos excluidos del poder local, que lo desean, y que han intentado por diversos medios, singulares o colectivos, penetrar en el concejo. Es decir, desde cada caso concreto, la entrada en el cabildo no es un acto accidental, sin precedentes, sino el fruto de negaciones pero también de la unión de fuerzas, de conversaciones, de planes organizados en donde los interesados por lo general calculan cada paso a tomar. Se conforman así grupos cohesionados, unidos, se crean estados decididos a llevar sus proyectos a la plasmación.

Lo dicho es totalmente necesario para poder establecer una lucha que se sabe larga en el tiempo: lucha que primero exigirá tener una representación por mínima que sea en su concejo, alegando no sólo habilidad para ejercer el portiello en cuestión sino también conjugando esto con la justicia que entraña que aquéllos que poseen cualidades y calidades distintas sean juzgados o gobernados en parte por quien sea su igual: en esto es indiferente el origen de la desigualdad. Me refiero a que durante el siglo XV será éste, argumento utilizado indistintamente tanto por quienes se sienten más honrados por su condición y la sociedad en parte les reconoce esta honra, que por aquellos grupos que independientemente de como se estimen son considerados por la sociedad como maculados, infamados en algún modo o manera.

La diferencia vendrá con el tiempo: los infectos y sus descendientes abandonarán o lo pretenderán, el discurso antes citado pues tornados cristianos y pasadas las generaciones lo que fue privilegio -el portiello o portiellos en virtud de su calidad- se tornó nueva mácula que los señalaba por siglos en su ascendencia infame ${ }^{16}$. Por el contrario, aquéllos que se jactaban y honraban en su diferencia no sólo no descartarán la argumentación de su distinción, de su excepcionalidad, sino que la incrementarán arropados por la ideología expandida por la Monarquía, en tal grado que justificándose en ella no sólo solicitarán su entrada en concejo, sino que de ahí pasarán a exigir la mitad e incluso el entero gobierno de sus localidades. Comparando Consuegra o Almagro, Villarrubia de los Ojos o Arenas de San Juan, en donde en un inicio se contentaron estos estados digamos dignos - nobles y ca-

${ }^{16}$ Las persecuciones y recordatorios de ascendencia infecta se daba con cualquier excusa, como lo demuestran estas dos consultas de viernes. La primera de 12 de mayo de 1581: "La villa de Argamasilla hizo relaçión en Consejo que por el día del Corpus Christi se hazía una dança de judíos y diablos, de la qual resultaban yncombinientes y diferençias. Pidió se mandase quitar. Diose provisión para que el alcalde mayor ynformase. El qual diçe es ansí y que combiene se manden quitar del todo y representa muchos ynconbinientes. Con esta provisión y respuesta piden lo mesmo. Fue encomienda del señor liçençiado Gamboa. No la aya y se dé provisión», AHN, Consejos, Leg. 7046. La otra más explícita y que nos retrotrae, por sus sujetos, al caso del niño de La Guardia, es de 12 de octubre de 1576 y dice: «Johan Franco y Gonçalo Franco y consortes, vezinos de la vila de Cabeça el Buey, hiçieron relaçión que en aquella villa se husaba haçer çiertos disfraçes deshonestos y afrentosos con máscaras y espeçialmente los que se haçían el día de Corpus. Pues en este pasado llegando a las puertas de sus casas se hechaban hechos judíos colgando de las rejas, so color de afrentarlos. Y porque les abían dicho que lo no hiçiesen avían acochillado a uno de ellos de que avía estado mal herido. Diose provisión para que informase el alcalde mayor y hordinarios. Y por ella paresçe que por causa de los dichos disfraçes avía avido çiertas heridas y que se avía proçedido contra los culpados y condenádolos en çiertas penas. E ahora piden no se hagan semejantes juegos ni disfraçes. Visto por encomienda del señor Cobarrubias, se mandó poner en consulta. Que la justiçia no consienta haçer disfraçes donde aya deshonestidad ni de que pueda resultar escándalo», AHN, Consejos, Leg. 7043. 
balleros - con un solo oficio, por lo general una alcaldía ordinaria, con un caso levemente posterior, de no más de un cuarto de siglo, como el de Madridejos en que se solicita la mitad de todos los oficios, se puede entender hacia dónde se encaminaban las pretensiones hidalgas y el salto cualitativo dado ${ }^{17}$.

Novedad pues en muchos concejos hasta entonces pecheros - de labradores o caballeros pero en origen pecheros- que con ella se enriquecen en su composición ${ }^{18}$. Novedad que como el aceite derramado se esparce lentamente desde las localidades en donde surge por vez primera, hacia las de su entorno y así sucesivamente. Pero novedad que más que apaciguar ánimos, dando cabida a todos en el ejercicio del poder, terminando con los conflictos sociales, los acrecienta dado que sobre todo y esencialmente la nobleza aspirará siempre a más.

Otrosy, porque en algunos pueblos de estos reynos no consienten que los hijosdalgo entiendan en las cosas del pueblo, ni tengan alcaldías, ni alguazilazgos, ni regimientos, ni otros ofiçios, ni entren en sus ayuntamientos, suplicamos a Vuestra Magestad que, pues los hijosdalgo son de mejor condiçión que los pecheros, mande que sean admitidos en los dichos ofiçios syn que ninguna cosa lo ympida. A esto vos respondemos que mandaremos a los del nuestro Consejo hablar y platicar para que se provea lo que sea de justiçia ${ }^{19}$.

${ }^{17}$ El discurso de la superioridad no es exclusivo de los nobles, por ejemplo los cristianos viejos de Abanilla lo usarán: «lo otro porque habiendo como ay en la dicha villa bastante número de vezinos del dicho estado de Christianos Viejos para tener todos los dichos ofiçios, no solamente se les debe la dicha mitad, pero según leyes y pragmáticas de estos reinos en concurso de los demás vezinos de la dicha villa habían de ser preferidos en todos los ofiçios de justiçias y públicos del conçejo de ella y en ellos enteramente», AHN, OOMM, Archivo Histórico de Toledo, N 40124.

${ }^{18}$ Enriquecimiento que no sólo viene de la introducción de la nobleza sino al unísono también de otros grupos muy dispares. Ocurre, por ejemplo, en Villarrubia de los Ojos en donde desde el siglo XV había alcalde hidalgo y también había habido regidor, mercader y regidor morisco. En el siglo XVI (1577) convertida en señorío del conde de Salinas - no había ya sólo esa riqueza sino que se había aumentado introduciendo en las cosas de gobierno a los mismísimos pobres: «El alcalde mayor y ordinarios de Villarrubia de los Ajos, ynbían çierta relaçión al Consejo por provisión de Su Magestad sobre que Miguel Sánchez Conexero, vezino de la dicha villa, pidió que la eleçión de los ofiçiales del conçejo de ella se hiçiese toda junta por çinco años, como se haze en las Órdenes de Santiago, Calatrava y San Joan. Por los yncombinientes que resultan de nonbrarse unos deudos a otros. Y por la relaçión consta que combyene que la dicha eleçión se haga por çinco años y que de todos los estados que ay en la dicha villa se junten veynte personas: hidalgos, labradores, mercaderes y del barrio nuevo y algunos clérigos. $Y$ estos sean de los más ricos y de los medianos y de los pobres y juntos ante la justiçia nonbren los que an de ser alcaldes por todo el dicho tienpo de los çinco años. Nonbrando para cada un año quatro personas de todos los dichos estados, porque el conde de Salinas, cuya es la villa, escoje los dos que les pareze para alcaldes de los quatro que salen para los dichos ofiçios y estos dos usan el dicho ofiçio un año. Y para el dicho efeto por las dichas veynte personas se nombren veynte y quatro porque si durante el dicho tienpo muriere o se ausentare alguna persona, aya número de do se puede elegir y sacar quatro personas en cada uno de los dichos çinco años. Los quales se nombren conforme a la costumbre de la dicha villa para cada un año por el día de San Miguel se saquen las dichas quatro personas para que escoxa y elija el dicho conde las dos de ellas que an de quedar por alcaldes. Y por la misma orden se nonbren los alcaldes de la Hermandad para cada un año. Agora el dicho Miguel Sánchez suplica se le dé la probisión que tiene pedida. Visto por encomienda del señor doctor Aguilera se mandó poner en consulta. Diligençias: las quales hagan ante el alcalde mayor, llamada la parte del señor», AHN, Consejos, Leg. 7044.

19 CLC, Ordenamiento de Cortes de Toledo, 1525, Capítulo XLII. Esta cita, esta petición es la primera, que sepa, en la que en Cortes se solicitó la admisión de los hidalgos en concejos. Señal de que las aspiraciones de los hidalgos eran claras y también señal de la importante oposición de los que hasta entonces habían, en solitario, gobernado sus villas y lugares. 
El concejo, sus integrantes, poseían las casas de cabildo o de otros lugares para reunirse ellos y sus congéneres — so cierta normalidad- para establecer políticas, ataques y defensas, actuaciones necesarias, imprescindibles para realizar actividades complejas, pero mayoritariamente en estas medianas o pequeñas villas y lugares - en la mayoría del reino- las celebraciones de juntas y reuniones de grupos apartados del poder o no mayoritariamente establecidos en él, eran demasiado evidentes como para que pasaran desapercibidas y, en consecuencia, para no ser perseguidas conforme a ley y costumbre bajo la sospecha de estar cavilando actuaciones contra el Rey y sus justicias legítimas - la otra parte en conflicto. De ahí cartas de seguro, permisos de reunión, etc. dados por jurisdicciones superiores o por la Chancillería.

Nos el cardenal arçobispo de Toledo, etc., mandamos a vos el nuestro alcalde mayor de la nuestra villa de Caçorla, e a vos los alcaldes hordinarios de ella que veáys la petiçión de esta otra parte escrita. Y çerca de lo en ella contenydo no pongáys ynpedimento alguno a los dichos Hernando Amador y sus consortes a que se junten a comunicar y proveer lo que les conviene en la cabsa e negoçio de que en la dicha petiçión se faze minçión. Lo qual vos mandamos que así hagáys y cunpláys so pena de cada, çinco mil maravedís para la nuestra cámara a cada uno que lo contrario fysiere. Dada en Madrid a ocho de nobienbre de mil e quinientos e quarenta años. J. Cardinalis. Por mandado de su señoría ylustrísima. Johannes Ruiz de Amusco, secretario ${ }^{20}$.

Contando siempre con la excepcionalidad, la entrada de un nuevo estado en concejo suponía, como ya se ha dicho, un complejo entramado con un fin neta-

20 El mandato del cardenal de Toledo respondía a la siguiente petición: «Reberendísimo señor. Hernando Amador, vezino de la villa de Caçorla, por my y en nonbre de los honbres hyjosdalgo, vezinos de la dicha villa, digo que nosotros tenemos neçesydad de nos juntar a fazer nuestros ayuntamientos para hablar e fazer e otorgar todos aquellos contratos, cosas e casos que para el sustentamiento y defensión de nuestra hidalguías y esençiones e livertades que convengan fazerse y para hablar y repartir entre nosotros los maravedís que viéremos que son menester para el gasto y costas de los pleitos y otras cosas que pidiéremos. Y porque los alcaldes hordinarios y justiçia de la dicha villa, por razón del pleito que con ellos traemos nos tienen odio y podría ser defendernos que no nos juntásemos ni hiziésemos nuestros ayuntamientos e sobre ello nos farán proçesos y calunnias y otros fatigamientos. Pedimos y suplicamos a vuestra señoría ylustrísima mande dar su provisyón para que la justiçia de la dicha villa ni nos ynpida ni defienda los dichos nuestros ayuntamientos, ni sobre ello nos fagan proçesos ni otras calunnias algunas sobre pena que para ello se les ponga, para lo qual etc. Hernando Amador», ARChG, Hidalguía, Caja 136, pz. 2. No obstante no siempre eran los perseguidos los hidalgos, otras veces lo eran los pecheros que habían dominado el concejo pues en los pleitos de oficios no sólo estaban las partes sino también, a veces, grandes personajes o instituciones a la sombra, ocurre en Don Benito donde, en los años 30 del XVI, el conde de Medellín promovía la implantación de la mitad de oficios. Los pecheros en su momento a inicios del siglo XVI o finales del XV habían ganado pleito y ejecutoria en donde se excluía a los hidalgos del concejo, el año 1526, siguiendo la ejecutoria se hicieron las elecciones para el 27, pero el bachiller Juan Dorta, alcalde mayor del condado de Medellín, «prendió a los que fueron elegidos e los hijosdalgo quedaron con los ofiçios contra el tenor de la dicha carta executoria». Sin oficios y sin libertad consiguieron un auto de Granada, dado por lo oidores el 30 de enero de 1527, en que se ordenaba la libertad de los apresados y la realización de nuevo de las elecciones bajo supervisión de lo alcaldes ordinarios del pasado año. Pese a esto, y en una contienda que duró cuando menos hasta fines del siglo $\mathrm{XVI}$ en torno de la mitad de oficios, los pecheros acosados tuvieron que trasladarse a Villanueva de la Serena para allí dar poder y hacer una información de su difícil situación. De todo ello se derivó carta de seguro dada por Granada el 4 de marzo de 1535 en que se ordenaba al conde de Medellín que no persiguiera a los pecheros de Don Benito, ni les impidiera preparar sus juntas y actuaciones, cosa que el conde, en principio, acató el 8 de marzo de 1535, ARChG, Hidalguía, Caja 5005, pz.6. 
mente definido, no se trata, mantengo salvo excepciones, de algo repentino, sometido al capricho de las partes sino que es la culminación de un conflicto más o menos latente, a veces cruento.

Considerar a un estado como algo uniforme, puede resultar erróneo: que todos fueran nobles, caballeros, cristianos viejos o nuevos, mercaderes, etc., no implica que fuesen iguales. Existían diferencias de fama, de poder económico, sobre todo, de relaciones sociales que separaban a veces extraordinaria y radicalmente a unos de otros, etc. ${ }^{21}$. Pero el asalto al poder municipal los unía, no los igualaba, pero los cohesionaba ${ }^{22}$. Dentro de cada grupo conformado en estado existían líderes, los más decididos, pero también los más interesados, los que se beneficiarían más de conseguir el objetivo propuesto, cabecillas no siempre directamente discernibles, aunque se puede suponer que los que encabezan memoriales, demandas y poderes, cuyos nombres se repiten reiteradamente en la documentación, mientras otros unas veces constan y otras no, fueron los jefes de cada estado que buscó el poder concejil. Sólo un estudio localizado, caso por caso, de capacidades económicas o prestigios pueblerinos pudiera dar resultados más veraces, aunque en ocasiones las partes contrarias se encargaron bien de denunciar al cabeza del grupo oponente, tildándolo de revoltoso y cuando menos de ambicioso que buscaba dominar y no servir a la localidad en cuestión ${ }^{23}$.

21 Dice la probanza de Villanueva del Arzobispo de 1579, hablando sobre el común de pecheros: «Yten, si saben que de zinquenta años a esta parte y más tienpo y de tanto tienpo acá que memoria de honbres no es en contrario, entre los del estado de los Buenos Honbres Pecheros, vezinos de la dicha viIla, a avido y ay diferençias en la calidad de ellos, porque los unos an sido cavalleros de premia y de contía, los quales an mantenido armas y cavallo y a abido hobres ricos contiosos y así lo son al presente. Y otros a abido honbres pecheros llanos sin calidad de cavalleros ni de haçienda y en las dichas calidades se an diferençiado los unos de los otros, en calidad y estimaçión y cantidad de hazienda, lo qual saben los testigos», ARChG, Probanzas, Caja 9135.

22 Ejemplo de la desigualdad dentro de un mismo estado viene evidenciado en el siguiente testimonio realizado a favor de que los hidalgos de Alcañabate entrasen en concejo: «Dize que Rodrigo Pacheco e Arias de Tébar e Andrés de Alarcón e Juan Gómez de Peralta son onbres ricos e abonados y personas áviles e sufiçientes e espertos para qualesquier ofiçios públicos de la dicha villa e de otra qualesquier çibdad, villa o logar de esto reynos. Lo qual dize que sabe por el mucho trato e conversaçión que con ellos tiene, por ver como a visto, sabido e conosçido que son onbres de buen saber e abilidad e sufiçiençia para lo susodicho. E por aver visto e conosçido las hasiendas e bienes que cada uno de ellos tiene, e por saver que son ricos e honrados, de buena fama e trato e conversaçión. E tales personas que mereçen bien e se les podía dar e confiar de ellos por saber e poder que tienen e mereçen qualquier ofiçio público de la dicha villa, e que son personas que de ello darían buena cuenta. E que asymismo sabe e a visto e conosçido al Bernaldino López e a Juan Gabaldón e Pedro de Lomas e Juan de Rabé e Juan del Canpo que son honbres de buenas hasiendas e honrados e que son áviles e sufiçientes e espertos para en qualesquier ofiçios de la dicha villa. Lo qual sabe porque ha visto e tratado e conversado con ellos e que a los otros demás contenidos en la pregunta antes de ésta, dize: que sabe e a visto que Gómez de Peralta tiene una casa en que bibe e çiertas viñas, e al Alonso Daraque le conoçe tener otra casa e viñas e una casa e un rosín, e que Diego de Castañeda tiene solamente una casa. E que son avidos e tenidos e comúnmente reputados por de buena fama, trato e conversaçión. E que el Alonso Daraque es honbre bien sabido e ábile e sufiçiente e esperto para qualesquier de los dichos ofiçios. E que el Gómez de Peralta e Diego de Castañeda son honbres de poco saber e que an seydo e son por tales honbres de poco saber e abilidad tenidos e avidos comúnmente por los vesynos e moradores de ella» ARChG, Elecciones, Caja 501, pz. 5.

${ }_{23}$ Un caso, el de la probanza del concejo de La Morera, hecha en enero de 1578 en que se pregunta por el líder de los hidalgos y sus verdaderas razones para pedir la mitad de oficios: «Yten si saben que 
De lo dicho la diversidad que se evidencia en los pleitos de mitad de oficios vistos por cualquier jurisdicción, la parte contraria suele establecer una dicotomía, manifiesta en la parte con la que se enfrenta: unos, los que se podrían considerar capacitados para ejercer oficios, bajo las concepciones de entonces, no son presentados como ricos y abonados y conocedores de la cosa pública, sino como poderosos - término utilizado peyorativamente-, como ambiciosos que buscan el poder por el poder; los otros, miembros también de esa facción, suelen ser tachados de condiciones que los inhabilitan, como puede ser el ser pobres, burdos, toscos, borrachos, etc., destacando que son utilizados maliciosamente por los primeros para, todos juntos, establecer el argumento del más que suficiente número que los convierte en estado relevante dentro de la población en cuestión ${ }^{24}$.

$Y$ es que pese a los comienzos de la venalidad de regidurías $y$ otros cargos ya en el siglo XV, aún se defendía, y se defendió hasta fines del Antiguo Régimen, la esencial perversidad que suponía para el buen gobierno de la república que los oficios se mantuvieran siempre en las mismas manos, en las mismas personas y gru-

Hernández de la Bastida, estando en esta Corte, siguiendo los dichos pleitos se jató y alabó a muchas personas que no pretendía los susodichos ofiçios sino para destruir el dicho conçejo e a çinquenta bellacos del pueblo. Y a hecho y haze por obras lo susodicho, de más de ello a talado y tala los montes y a defraudado y cobrado dineros del conçejo, siendo ofiçial de penas y de otras cosas y no los a dado ni asentado en el libro del dicho conçejo", ARChG, Probanzas, Caja 9131.

${ }_{24}$ Constantina, 1579, probanza del concejo y hombres buenos pecheros realizada contra los hidalgos y la mitad de oficios, pregunta cuarta: "Yten si saben que los dichos Johan Hidalgo e Rodrigo Hidalgo, su hermano, de más de ser forasteros como dicho es, son ombres que usan y exerçitan ofiçios viles y muy baxos. Porque uno de ellos es molinero de moler pan y carbonero y el otro es pastor que guarda cabras y obejas a soldadas y muy pobres, sinples, de rudo y tosco entendimiento y no ábiles ni sufiçientes para thener semejantes ofiçios. No solamente en un lugar tan grande y prinçipal como es la dicha villa de Constantina, pero ni en otros ningunos y que por persuçiones del dicho Rodrigo de Neyra se mobieron a poner la dicha demanda y no porque ellos tuviesen ni tienen pretensión a los dichos ofiçios. Y el dicho Rodrigo de Neyra es honbre poderoso y que sin la dicha ocasión de tener ofiçio en el conçejo tiene comidos y destruydos los propios y rentas del conçejo y le es deudor de muncha cantidad de maravedís y a talado y comido con sus ganados las dehesas. Y es hombre escandaloso y que tiene y sustenta bandos y que si se a movido a pretender la dicha mitad de ofiçios es para vengarse y destruyr a munchos hombres honrados y ricos de la dicha villa. Y si el dicho Rodrigo de Neyra saliese con su pretensión, todos ellos se yrían a bibir fuera del dicho lugar. Y el dicho Lope de Neyra, su padre, es hombre de hedad de más de septenta años, ombre enfermo de perlesia y a más de çinco años que no sale ni puede salir de su casa por estar tullido de la dicha ynfermedad, por lo qual está ynabilitado de poder usar exerçer ofiçio de ofiçial, digan etc.», ARChG, Probanzas, Caja 9135.

${ }_{25}$ Pese a que por sus defensores se propugnaba la mitad de oficios como medio idóneo para que los oficios, hasta ese momento ocupados por una u otra facción de poderosos, cambiasen con regularidad de manos, lo cierto es que la misma mitad de oficios desde sus inicios llevaba en su seno la potenciación de la perpetuación. Siendo necesariamente, por lo habitual al sur del Tajo, mucho más numeroso el estado no noble que el hidalgo, los oficios destinados a éste último se acumulaban en unas mismas personas. Y esto por diversas causas que pueden ir desde que en muchas poblaciones el grupo más significativo dentro del estado hidalgo no quería elegir a algunos componentes suyos, por pobres, enemistades, etc., o bien hasta llegar a que el estado hidalgo, por muertes, emigraciones, pasos a la pechería de determinadas familias, etc., quedase tan reducido que hubiese más cargos de hidalgos que hidalgos mismos, que año tras año se presentaban y eran automáticamente — por falta de competenciareelegidos. Esto llevó a casi la perpetuación fáctica de estos oficios de nobles. Por ello los pecheros siempre solicitaron que se respetara y a veces, más de una lo conseguían, así lo solicitó en pleito de mitad de oficios de Almansa, Melchor de Aguilera, asesorado por el licenciado Cañete, que decía el 16 de noviembre de 1584, entre otras cosas que la provisión sobre huecos había de guardarse, «mudando los ofiçios, y si no se hiziese nunca saldrían de la parte contraria por no aver como no ay en la dicha villa, 
pos, y contra ello las normas que establecían huecos, etc., si bien sólo, creo, tenían su ejecución asegurada a instancia de parte, de la parte contraria que no es que le repugnara el sistema, sino que se oponía a que un enemigo político o grupo de enemigos se apoltronasen en los concejos, sin remedio ni cambio alguno ${ }^{25}$.

Resulta difícil, volviendo a la complejidad de la estructuración y actividad de los partidos en lid, hallar más documentación que la estrictamente oficial y como mucho suelen ser los poderes a procuradores los que nos dan noticia, escasa por otra parte, de las actividades previas y métodos de actuación preconcebidos por los grupos que, por ejemplo deseaban acaparar poder. No he encontrado ninguna de la Baja Edad Media para la parte sur del Tajo, pero sí se puede utilizar la excepcional documentación del pleito de mitad de oficios de Cazorla, de la primera mitad del siglo XVI, para hacernos una idea de conversaciones y planificaciones.

Se trata de la concordia efectuada entre los hijosdalgo de Cazorla que querían ser oficiales, por mitad, con los caballeros de cuantía a los que notificaron su demanda:

\section{CABALLEROS DE PREMIÁ DE LA VILLA DE CAZORLA QUE FUERON NOTIFICADOS EN 1540}

\begin{tabular}{|l|l|}
\hline Antón de Jorquera, alcalde ordinario & Cristóbal de Caravaca, regidor \\
\hline Rodrigo Zarco, regidor & Fernán Jiménez el gordo, regidor \\
\hline Pero Fernández Garrido, regidor & Cristóbal de Portillo, mayordomo de concejo \\
\hline Juan de Torres de la Corredera, alguacil ordinario & Pedro de Toledo, el mozo, almotacén fiel \\
\hline Pero Fernández de Estepa, caballero de sierra & Pedro de Torres, caballero de sierra \\
\hline Fernán López de Tero, alcalde de acequias & Sancho de Córdova, obrero del concejo \\
\hline Cristóbal Muñoz de Bustos, fiel almotacén & Alonso de la Plaza, escribano \\
\hline Juan de Navarrete, escribano & Rodrigo de Cazorla, escribano \\
\hline Diego Martínez de Jerez, escribano & Diego de Tíscar, personero del concejo \\
\hline Diego Fernández Polaino & Ginés del Castillo \\
\hline
\end{tabular}

sygún ellos dizen, otros más que ellos del estado de los Hijsodalgo y esto no a de ser causa para que se quebrantase lo que tan justamente está proveydo y ordenado y es general en todo el Reyno", ARChG, Elecciones, Caja 4711, pz. 6. Contra ello los concejos en donde el grupo pechero era poderoso, igual o más que el hidalgo, mantuvieron distintas respuestas. Una, la supresión de la mitad de oficios. Otra, como en Almansa, la defensa y si se podía la ejecución de la práctica de huecos ordenada por las leyes, oficios pues que o quedaban vacantes o eran ocupados por pecheros, como se denominaba, en depósito (fulano, alcalde ordinario por el estado de los Hijosdalgo en depósito). No siempre triunfaron los pecheros con estas medidas, pero sí es cierto que motivaron numerosísimos litigios durante todo el siglo XVI en especial durante el reinado de Felipe II y que incluso la ley recopilada que ordenó que no se guardasen huecos, si no había número suficiente, entre los hidalgos, no llegó a cumplirse siempre en virtud de provisiones anteriores ganadas, de costumbres o de los simples mismos hechos y la Monarquía, por otra parte, no siempre actuó a favor de los nobles. Un ejemplo a favor de los nobles puede ser el siguiente y éste al norte del Tajo, el resumido en la siguiente consulta trigésimo octava resuelta el viernes 25 de mayo de 1576: «El estado de los Hijosdalgo de la villa de San Çebrián, çerca de las Amayuelas, 


\begin{tabular}{|l|l|}
\hline Lorenzo de Segura & Pedro de Tejerina de la Tejera \\
\hline Luis Martínez Colmenar & Bachiller Gabriel del Castillo \\
\hline Cristóbal Rodríguez & Jorge Trapero, mercader \\
\hline Juan de Baeza & Alonso de Estremera \\
\hline Juan de la Muela & Jerónimo de Peralta \\
\hline Juan Sánchez Pastor & Pero Fernández Pastor, hijo del colateral \\
\hline Martín Sánchez de Quesada, hortelano & Pedro de Galeno \\
\hline Juan Cano de Segura & Cristóbal Gallego \\
\hline Francisco Ruiz Tamargo & Bartolomé López de Úbeda \\
\hline Alonso Pérez de Logroño & Juan del Carpio, carpintero \\
\hline Francisco Martínez, carpintero & Fernán López Merino \\
\hline Juan López Villarón & Pero Barroso \\
\hline Antón Rodríguez Adalid & Martín de Santisteban \\
\hline Francisco Ortiz & Pedro de Uceda \\
\hline Juan del Alcázar & Juan Rodríguez Arradienron \\
\hline Andrés López de Hornos & Cebrián Medel, sastre \\
\hline Diego de Sabiote & Pero Gómez de Carmona \\
\hline Juan Izquierdo & Juan de Illescas, zapatero \\
\hline Alonso Gómez, carnicero & Cristóbal Ramos, especiero \\
\hline Pedro de Alcalá Moreno & Pero Fernández Medel \\
\hline Bartolomé Rodríguez & Miguel de la Fuente \\
\hline
\end{tabular}

La concordia hidalga se hizo en las casas de Hernando Amador de Lezcano el 19 de noviembre de 1540 y posee cinco vertientes destacables:

\footnotetext{
tiene carta executoria de la Chançillería de Valladolid para que les den la mitad de los ofiçios y otra executoria librada el año de 64 en Valladolid en que se declara que de allí adelante en los ofiçios que en la dicha villa ay, no aviendo número de hijosdalgo para poder ser elegidos a los dichos ofiçios, los tales hijosdalgo puedan ser rehelegidos sin enbargo que ayan tenido otros ofiçios los años pasados. Estando esto así por parte de un Juan Herrero se llevó la provisión ordinaria del Consejo para que no sean rehelegidos. De la qual suplica la parte del estado de los Hijosdalgo, porque dizen que no se entiende con ellos, porque no aviendo número como no le ay, pueden ser rehelegidos y de ello tienen carta executoria. La parte del Juan Herrero pide que sin enbargo de su respuesta y de la carta executoria se le dé sobrecarta de la provisión ordinaria que llebó del Consejo. Visto por los señores Redin, Villafañé, Chabes, Aguilera, don Fernando, don Lope. Lo mandaron poner en consulta. Relator Ramírez. No a lugar la sobrecarta i sigan su justiçia» AHN, Consejos, Leg. 7043.
} 
1. Decisión de un grupo lo suficientemente numeroso con un común y determinado fin: la consecución de la mitad de oficios en virtud de su condición de hidalgos constituidos en estado, junto con el establecimiento del enemigo común, aquí el concejo dominado por cuantiosos.

2. Elección de la persona o personas que representarán a ese estado y se encargarán de dirigir tanto las actividades conjuntas del mismo como las medidas que sean necesarias en caso de pleito. Persona que puede coincidir con el cabecilla principal, como parece en este caso de Cazorla, y a la que se le suele dar poder en nombre de los demás compañeros.

3. Establecimiento de una retribución al dirigente encargado del desarrollo de las actuaciones así como el establecimiento del abono de los gastos de todo tipo que realice con tal motivo ${ }^{26}$.

4. Creación de una estructura financiera —cogedor, repartidores, etc.- así como el otorgamiento del compromiso para todos los firmantes de hacer frente a lo que se les reparta para la asunción de los gastos.

5. Por último, pese a ser un conjunto de personas constituido en estado, éste no siempre está conformado por todos los que poseen una misma calidad, lo que produciría que soportando los costes unos se beneficiaran también otros, así lo establecía la ley, por lo que los conjurados establecían cláusulas que por una parte pretendían atraer a sí a los todavía indecisos o contrarios a las actuaciones prefijadas y por otra parte en ellas se acordaba contra legem- que independientemente que poseyeran la calidad exigida, aquí la hidalguía, si no contribuían, por no querer o por avecindarse con posterioridad, sólo se les permitiría participar y ser elegidos si abonasen al resto de los actuantes la cantidad proporcional que les hubiese cabido ${ }^{27}$.

Pero si los que buscaban su entrada en el concejo, en sus juntas y ayuntamientos configuraban estrategias y marcaban objetivos, los hasta entonces domi-

${ }^{26}$ Que lo hidalgos se juramentaran y decidieran hacer frente a los gastos de los pleitos de mitad de oficios entablados, no quiere decir que después todos los conjurados cumpliesen. A veces había que recurrir a la Chancillería para que pagasen como lo atestigua esta provisión dada en Granada el 29 de diciembre de 1577 y dirigida a algunos hidalgos poco amigos de gastar sus peculios: «Don Felipe, etc., a vos Juan Mexía Çapata y Gonçalo Ruiz Hidalgo y Gonçalo Rodríguez, hijo de Blas Rodríguez, y Françisco de Bargas y Pedro de Olibera y Juan de la Bastida y Juan Rodríguez, hijo de Gonçalo Rodríguez, y Hernando Alonso, vuestro hermano, hijosdalgo que os desis ser y vezinos de la villa de Salvatierra, salud y gracia. Vien sabéis e devís saber el pleito que ay ante la nuestra Corte y Chanzillería ante el presidente y oydores de la nuestra Audiençia que reside en la çibdad de Granada entre vos con el concejo de la dicha villa de Salvatierra sobre que razón de la mitad de los ofiçios del concejo y sobre las demás causas razones en el pleyto conthenidos. En el qual por parte de vos lo susodichos y por Felipe Velázquez, vuestro procurador en nonbre de vos fizo relación diziendo que algunos de vosotros, que avíades dado poder para seguir el dicho pleito, no queríades contribuir en las costas y gastos de él. Y nos suplicó le mandaseis dar nuestra probysión en la dicha razón, para que contribuyésedes en las costas y gastos que se an fecho y fizieren en el dicho pleito asta el día que os apertéis de él. Y por nos visto fue acordado que devíamos dar esta nuestra carta para vos en la dicha razón y nos tuvímoslo por bien, por la qual vos mandamos que luego que con esta nuestra carta fueredes requerido, contribuyáis rata por cantidad cada uno de vos en las dichas costas y gastos del dicho pleito lo que saliere a pagar», ARChG, Registro del Sello, Caja 6259.

${ }^{27}$ La trascripción extractada de la concordia véase en el documento $n^{\circ} 8$ del apéndice. 
nadores del municipio igualmente, en actos similares, concebían actuaciones muy diversas, pero que pueden, dentro del múltiple casuismo, ser evidenciadas, dentro de ellas, las más usuales.

1. Utilización de todos los mecanismos, por pobres que pudiesen ser, que les brinda el aparato municipal que dominan.

2. Utilización del concejo como centro virtual en torno al cual se unen las personas y familias que hasta entonces han gobernado la política local, con el objeto de desarrollar una defensa común.

3. Utilización de fueros, costumbres, usos, ordenanzas, etc., en definitiva de cualquier fundamento en Derecho que sirva para negar la innovación electoral y estructural concejil.

4. Defensa de la paz socio-política hasta entonces disfrutada en virtud de las estructuras que se pretenden novar, novación que acarrearía el fin de la paz de la localidad y sus buenas costumbres ${ }^{28}$.

5. Mantenimiento de sus defensas a través de los recursos económicos municipales ${ }^{29}$.

6. Presiones, basadas en ley, para debilitar a los contrarios y que pueden efectuar gracias a la dominación del municipio ${ }^{30}$.

28 Así decían las partes pecheras y hasta entonces dominadoras del concejo en la villa de Berzocana (1594) «No ai si solos tres o quatro que se dizen hijosdalgo, i entre ellos andaría tiranizada la justiçia, por averse de reelegir a falta de otros y ellos entre sí son padres y hijos, suegros y yernos, hermanos y primos de manera que ni ay número de hidalgos, ni razón para que se altere el buen govierno en que la dicha villa se mantiene», ARChG, Elecciones, Caja 1582, pz. 4.

${ }_{29}$ Esto último era una de las cosas más perjudiciales a las partes hidalgas y motivo principal de que los hidalgos solicitasen cuando les convenía que se declarase que no se atacaba al concejo sino a los particulares pecheros. Pero, como es sabido, no sólo eran los pecheros los que se saciaban de los dineros concejiles. Por ejemplo en Alcaraz se seguían muchos pleitos sobre hidalguía de los poderosos y familiares de ellos que ocupaban los portiellos, pero el común y su procurador no se dejaban amilanar recurriendo una y otra vez a la Chancillería, institución que siempre atendió favorablemente las peticiones de un casi heróico procurador síndico, llamado Francisco Gallego, que no cejó ni un momento ante los que eran y querían ser hidalgos. Una de las veces recurrió a Granada quejándose de la falta de dinero para seguir la defensa del común pues «todos pretenden una misma cosa: que los pleytos no se sigan porque no se sepa la verdad ni sea hecha justiçia contra ellos. Y aunque por él an sido requeridos no quieren pagar lo que se debe y no ay dineros para lo por benir, antes an procurado de gastar los propios de la çibdad en otras cosas porque no aya dineros para estos pleytos. De cuya cabsa la dicha çibdad no los puede seguir ni él en su nonbre como le conbiene y todo lo que por su partes en ellos se a hecho y haze a seydo y es con muy grand trabajo y contradizión». En la tónica dicha, la Chancillería ordenó al receptor Gonzalo del Valle, en 10 de octubre de 1543, que fuese a Alcaraz y cobrase y entregase a Gallego 200 ducados y que si no se los daban, que ejecutase a los que se oponían a ello, ARChG, Hidalguía, Caja 5088, pz. 125.

30 Los hidalgos de Mengíbar, en 1602, se quejan de las presiones que como concejo les hacían los caballeros de cuantía a raíz del pleito que habían ganado pero que no se respetaba y lo intentan probar «Yten, que mandándose por la dicha real executoria que la mitad de los dichos ofiçios se den a los hijosdalgo que ubieren en esta villa, y aunque los ay en ella e por su parte se pidió al dicho conçejo les admitiesen en la dicha eleçión y que se les diese la dicha mitad de oficios como lo manda Su Majestad, los dichos ofiçiales no lo quisieron admitir. Antes maliçiosamente le van buscando y buscan y lebantan pleytos, sólo a fin de ynpedirles que no tengan los dichos ofiçios, causándoles muchas costas y daños", AHN, Consejos, Leg. 33061. 
Aunque similares no son idénticas las actuaciones, pues diferentes son las posturas de partida: ataque y defensa. No obstante existen también muchos puntos en común.

Uno de ellos podría ser la negación recíproca de la beneficencia política de lo ya establecido o de lo que se pretende establecer. En ambos casos la tesis defendida es alegada como la solución definitiva para que la sociedad se convierta en una república perfecta en donde sus gobernantes no gobiernen por la simple ambición, sino por el beneficio común, apartando de sí la corrupción, la endogamia, la explotación de los más pobres, etc ${ }^{31}$.

Otro sería la reivindicación que cada parte hace de las cualidades y calidades personales que adornan a sus componentes y, a la vez, la denigración que también cada parte realiza de sus oponentes. Descalificaciones que los inhabilitan para gobernar e impartir justicia y ataques que se efectúan tanto de forma conjunta como particular ${ }^{32}$.

Por último y entre muchos puntos comunes y ejemplos de ellos, estaría la pretendida justificación de sus peticiones en la Justicia, en lo justo, todo lo cual está amparado por el Derecho - leyes y costumbres- del reino que avalan de forma indiscutible el derecho exigido.

\section{SEMEJANZAS Y CONTINUIDADES EN LOS SIGLOS XV Y XVI EN LA MITAD DE OFICIOS CASTELLANA}

Al igual que el monopolio del poder local no es sólo propio del bajomedievo y de la Edad Moderna, tampoco lo es la existencia de concordias o sentencias que establezcan el reparto de ese poder entre diferentes grupos sociales, diferenciados unos de otros. Grupos sociales que no necesariamente se resumen en nobles y vi-

31 En el pleito entablado en Don Benito para mitad de oficios, en 1536, los testigos de los hidalgos, que ya habían tenido representación en el concejo aunque no por mitad, alegan lo beneficiosa que había sido esta participación en comparación con los tiempos totalmente pecheros: «A la quinta pregunta, dixo que lo que sabe es que dende que los dichos fidalgos del dicho lugar de Don Benito tienen los dichos ofiçios, estuvo absente del dicho lugar hasta que avía seys meses poco más o menos que vyno al dicho lugar, e dende entonçes hasta agora ha visto que el dicho lugar ha estado muy bien regido e governado e muy mejor que estava en el tienpo que los pecheros tenían los dichos ofiçios e le han dicho cosas que han fecho, las quales este testigo ha visto de que al dicho lugar ha seguido mucha utilidad e provecho e por esto sabe que sería muy útil e provechoso que los dichos hidalgos del dicho lugar de Don Benito tuviesen los ofiçios del conçejo del dicho lugar», ARChG, Hidalguía, Caja 4992, pz. 4.

32 Habiendo pleito sobre elecciones en la villa de Ceheguín, enfrentadas las familias de los Hernández Torrecilla y los Corbalán, no sólo por el primer pleito comentado sino a la vez por disputas de herencias, las ofensas para inhabilitar a la últimos socialmente y como posibles oficiales, llegaron a alto grado: «de munchos días a esta parte ellos e los demás culpados, por ynjuriarlos y afrentarlos y macular su honra, avían dicho contra los dichos sus partes e los demás de su linaje que eran unos confesos ruines y espeçialmente en un día de este presente mes de mayo (1578) sin causa ny ocasión alguna aviendo querido tener pendençia con el dicho Gaspar del Bayo, los dichos Alonso Hernández y su padre le avían dicho al dicho Gaspar del Bayo y a los demás sus partes y a los de su apellido y linaje que eran unos putos confesos que avían de estar abrasados... que los corbalanes y chinchillas avían de estar quemados», ARChG, Probanzas, Caja 9130. 
llanos, no siendo cierta, por tanto, la teoría alegada en muchos casos y a veces recogida por la historiografía que impediría distinciones o divisiones políticas entre grupos sociales de igual calidad o condición.

Es en sí, la mitad de oficios una institución incardinada en lo que se ha denominado como división de estados y, en este caso, mitad de oficios que se ciñe exclusivamente al ámbito local. Institución pues que tiene orígenes medievales pero que por circunstancias diversas resplandecerá en los finales de la baja Edad Media y sobre todo en la Edad Moderna y, dentro de ella, durante el siglo XVI y comienzos del XVII.

No obstante siendo una institución de antiguas raíces, aunque evoluciona y se renueva, mantuvo una serie de coordenadas durante su vigencia, sobre todo entre la baja Edad Media y la Moderna, concretamente entre los siglos XV y XVI.

Su implantación obedece a contiendas sociales, excepcionalmente y aunque no conozco caso alguno, pudo ser derivada del puro acuerdo entre partes, pero lo usual y mayoritario es que nazca o bien desde la imposición de la fuerza, o bien por el arbitraje de un ente o persona superior a las partes, o, como fue lo más usual, por medio del litigio.

Litigio, contienda jurisdiccional al no avenirse las partes a ningún acuerdo, pero litigio que en sí no posee o tiene que poseer una jurisdicción única que pueda entender de él. Mientras que pleitos sobre determinados asuntos, como el pleito pleno de hidalguía, eran caso de Corte —éste desde Juan l- y sólo, en teoría, podía ser conocido en primera instancia por los alcaldes de los Hijosdalgo, los pleitos de mitad de oficios, por ejemplo en territorio de Órdenes Militares se veían por las justicias ordinarias de esas instituciones y de igual manera podía suceder en realengo, como en Sevilla y su tierra, durante cierto tiempo.

Pero pleito de mitad de oficios que, si se estimaba oportuno, podía constituirse, naturalizarse como caso de Corte, no por la cuestión debatida, no por el fondo, sino porque una de las partes era un concejo y así las Audiencias y Chancillerías se convertían en únicos jueces naturales del mismo, por ser contra concejo.

Ese factor y según las vías de defensa y ataque de las partes sirvió, de hecho, para que se utilizara en favor de quien creyera que una jurisdicción le sería más benévola que otra, o que, utilizando más de una al unísono podría alargar en el tiempo las actuaciones de la parte contraria en tal modo que ésta por hartazgo, persecuciones, presiones o falta de recursos terminase retirándose ${ }^{33}$.

33 El 15 de octubre de 1567, Gonzalo Hernández de Espinosa, Rodrigo Montes, Pero Vázquez y Diego Vázquez, hijos de Vasco Pérez, Rodrigo Alonso Castellano y Juan de Espinosa, hijosdalgo, por ellos y en nombre de los demás demandaron a la Chancillería la mitad de oficios, en base que era «notorio que los hijosdalgo regirán y administrarán mejor los dichos ofiçios». Utilizando el juego de las cuestiones de competencia el concejo pechero presentó la siguiente petición a la Corte de Granada «Muy poderoso señor. Rodrigo Alonso de Trigueros en nonbre del conçejo, justiçia y regimiento de la villa de Fuentes del León, respondiendo a una demanda de Gonzalo Hernández de Espinosa y sus consortes digo, ha- 
Así por dos vías podía ser visto en las Audiencias: en apelación o como es más común por nueva demanda exigiendo su reconocimiento como caso de Corte.

Pero con el tema de su naturaleza no sólo se creaban cuestiones de jurisdicción, que eran utilizadas como instrumento en favor o en contra, sino que durante los litigios podían variar calidades incluso dentro de un mismo juzgado. Muchas fueron las situaciones en las que los que demandaban al inicio y por conveniencia que fuese caso de Corte y así lo presentaban ante la Audiencia, que lo admitía, ordenando, de este modo y expresamente, que cualesquier otras jurisdicciones se apartasen, digo que esos mismos que habían presentado todo como caso de Corte, en primera instancia o ya en apelación ante el presidente y oidores, cambiaban maliciosamente sus argumentaciones, expresando por medio de procuradores y letrados que no era ya caso de Corte por ser contra concejo como arguyeron en principio, sino que sólo se iba contra el estado de los Labradores, de los Pecheros, de los Caballeros de Cuantía, etc., contra particulares y no contra instituciones.

Porque este pleito es pleito de entre particulares que pretenden su ynterés, e de ello no resulta provecho universal al pueblo, antes si se oviese de seguir a costa del conçejo este pleito avía de ser por parte de los hijosdalgo, porque más cosa conveniente es que los hijosdalgo rijan y manden los pueblos, que no los pecheros, porque por la mayor parte los hijosdalgo son personas de mejores entendimientos y están abituados y criados a tratar con personas nobles y siendo nobles es de creer que usarán virtud como sus pasados, porque la nobleza se les dio por aver usado virtud, lo que no concurre así en los omes buenos pecheros, en los quales no se mira otra cosa para ser admitido a los ofiçios sino que tenga çierta cantidad de maravedís de hazienda y es posible que aquella la ayan adquirido con maneras ylíçitas y ofiçios baxos, de lo que pareçe claro que se se uviese de seguir este pleito a costa de conçejo avía de ser en quanto toca a la parte de los hijosdalgo y no a la de los pecheros ${ }^{34}$.

Lo peor es que sus argumentaciones solían ser consideradas como ajustadas, por lo que los oidores declaraban que el pleito era entre particulares y no contra concejo, con lo que por ejemplo si era un concejo de labradores pecheros y éstos hasta entonces se habían servido de propios y repartimientos para costear sus de-

\footnotetext{
blando con el acatamiento que devo, que vuestro muy reverendo presydente e oydores de esta Real Abdençia no son juezes de esta causa y la an de remitir al Consejo de las Hórdenes por la çédula que tiene esta Real Abdiençia en que se da horden que los negoçios tocantes a las preminençias y leyes capytulares de la horden y manda que estos negoçios y otros allí espresados se remitan al dicho conçejo de Hórdnes. A Vuestra Alteza pydo y suplico asy lo provea y mande y para que conste como este negoçio y demanda está deçedido por ley capitular y hago presentaçión de esta provysión del dicho Consejo de Hórdenes sacada con abtoridad pública para ello, etc. y pido justiçia y costas. Trigueros (Firmado y rubricado). El liçençiado García Sánchez (Firmado y rubricado). Granada en principio se inhibió, cosa que sorprende, pero siguiendo su tónica general en cuanto los hidalgos protestaron del cambio de jurisdicción, la Corte se declaró juez competente y el pleito siguió en Granada, ARChG, Hidalguía, Caja 4733, pz. 13.

${ }^{34}$ En agosto de 1543 habían apelado los hidalgos a la Chancillería como caso de nueva demanda y consideraban a ésta el tribunal idóneo expresamente por ser contra concejo, pero ya en 7 de marzo de 1544 el procurador Juan Ruiz de Soria solicitaba y argumentaba lo arriba transcrito, ARChG, Hidalguía, Caja 136, pz. 21.
} 
fensas, ya no podían seguir haciéndolo, debiendo recurrir a sus fortunas personales, lo que, o por no haber o por no gastar de lo suyo, resquebrajaba en mucho a esa parte y, a veces, es evidente la deserción de los que hasta entonces eran un grupo unido, dañándose en consecuencia sus posiciones y sus defensas en adelante y fortaleciendo a la parte contraria que pretendía entrar en concejo y que antes de nada y como ya se ha mostrado en el caso de Cazorla había establecido las vías para autofinanciarse.

No hubo una norma general para todo el territorio de la Corona de Castilla que ordenase la implantación de la mitad de oficios automática siempre que un estado con derecho suficiente lo solicitara, tampoco la hubo en contra de la institución. Pero las instituciones jurídicas no nacen necesariamente de una norma escrita, por lo que en ningún caso se puede establecer que la mitad de oficios fuese invención y abuso esencialmente nobiliario, apoyado sin limitaciones por la Corona a través de sus tribunales. Como otras muchas instituciones jurídicas medievales y modernas, estaba plenamente respaldada por el Derecho, por el Ordenamiento Jurídico, si no en un precepto concreto de naturaleza general, sí en costumbres, ordenanzas, doctrinas jurídicas, pero también en normas y no me refiero sólo a la manida y conocida de la Santa Hermandad sino a normas como las señaladas que facultaban el acceso a los ayuntamientos, en los territorios de las Órdenes Militares, a nobles y mercaderes. Es pues la mitad de oficios institución legítima, otra cosa es que fuese beneficiosa para el común, ni que viniese a reestablecer paces ${ }^{35}$.

No existiendo prelaciones concretas que pudiesen sin duda ser alegadas en Derecho ante los tribunales, ambas partes plantearon siempre la incongruencia, la

35 Por otra parte y sin desdecir lo anterior y pese a las peticiones en Cortes y las directamente elevadas al Rey por medio de consulta, la Monarquía no quiso implantar la mitad de oficios de forma absoluta por medio de una norma. Considerada, seguramente, como una forma de elegir y gobernar más y no perjudicial, sin embargo no la alzó a principio indiscutible, que hubiese ahorrado pleitos y controversias y todo lo que implican, pero que hubiera dado lugar a un poder cuasi absoluto a los nobles del Reino a nivel local. Como ejemplo de estas aspiraciones y exigencias legislativas nobiliarias que se arrastraban desde fines del XV y su denegación por la Corona, la décimo novena consulta vista el 28 se septiembre de 1576: «El reyno y los procuradores de Cortes de él diçen que, aunque es costumbre usada y guardada en todas las çiudades, villas y lugares que la mitad de todos los ofiçios onrosos, de justiçia y gobierno, se den a los hijosdalgo, por no estar estableçido por ley, en algunas de las dichas çiudades y billas contrabienen la dicha costunbre. Suplican se mande haçer y promulgar ley en que se mande que en todas las partes donde ubiere número de hidalgos se les den la mitad de los dichos ofiçios, sin enbargo de qualquier costumbre o executoria que aya en contrario. Oyese» AHN, Consejos, Leg. 7043. Al año siguiente se volvía a solicitar y se le daba igual respuesta: «Gutiérrez de Canpuçano en nonbre de estos reynos, dize que aunque es costunbre usada y guardada de tienpo ynmemorial a esta parte en todos estos reynos que en las villas y lugares de ellos donde se proveen ofiçios onrosos de justiçia y governaçión se dé la mitad de ellos al estado de los Hijosdalgo, y, por no estar esta costunbre estableçida por ley, en algunas de las dichas villas y lugares se contrabyene a ello en gran daño y perjuiçio de la república y de la nobleça. Por lo qual sería cosa conbiniente se mandase haçer y promulgar una ley sobre esta raçón en que se mande que en todas las dichas villas y lugares donde se huviesen de proveer por los conçejos de ellas los dichos ofiçios onrosos, se diese la mitad de ellos al estado de los Hijosdalgo abiendo número conpetente para ello, sin enbargo de costunbre o executoria que aya en contra. En la consulta pasada se respondió que se oye, suplica de lo proveydo y que todabía se mande haçer lo que tenía pedido. Confirmase lo proveydo», AHN, Consejos, Leg. 7044. 
confrontación de la mitad de oficios frente al pasado jurídico de cada localidad. Unos, los atacantes, estimando que el Derecho común, el Derecho regio, el Derecho señorial y local y, además, la pura lógica y razón impelían al establecimiento de esta institución en base primero de su igualdad y por tanto en base a sus derechos a ser considerados verdaderos vecinos y a beneficiarse de ello, y después a inicios del siglo XVI con claridad, aumentando conforme corría el siglo, a presentarse no sólo como iguales a los que hasta entonces habían ocupado el poder sino como superiores a ellos: más dignos, más idóneos, en definitiva como los verdaderos llamados al poder, no sólo a la mitad de oficios, sino al poder político en su totalidad, como los más fidedignos servidores de la república y del Rey ${ }^{36}$.

Por contra los que se defendían, los que hasta entonces habían gobernado en solitario sus concejos, argumentaban, lo injusto, lo innecesario y perjudicial de lo solicitado. Injusto, ilegítimo pues no sólo no había norma o costumbre lugareña ni general, precedente o coetánea, sino que se estaba atacando la esencia normativa y estructural de sus instituciones, de su concejo en concreto. Fueros, costumbres y ordenanzas respetadas - según los defensores- siempre, o casi, desde tiempo inmemorial se verían derogadas o cuando menos dañadas por la inserción de la mitad de oficios y así lo alegan en sus defensas ${ }^{37}$. Pero modificación jurídica

36 «Otrosí dezimos que conforme a las leyes destos reynos, en las villas e lugares dellos se deven y han de dar al Estado de los Hijosdalgo do los oviere, la mitad de los oficios del Concejo, y así se determina y manda por justicia en las Chancillerías de Vuestra Magestad. Y es así que en algunas villas y lugares ha acaecido que por colusiones y fraudes de los Concejos, y en otras partes por pobreza de los hijosdalgo, o por negligencia o descuido de sus pasados, han sido vencidos de los pleytos que sobre esto han tratado, y así están privados de los oficios que son suyos y tan justamente se les deven y se ven oprimidos y maltratados de los labradores, en cuyos lugares viven, por la enemistad que ordinariamente les tienen. Suplicamos a Vuestra Magestad, que pues es tan justo que el Estado de los Hijosdalgo sea honrado y favorecido y dellos más justamente se puede y deve confiar el servicio de Dios y de Vuestra Magestad, provea y mande generalmente, sin embargo de qualesquiera leyes y executorias, en todas las villas y lugares del Reyno tengan y se dé al Estado de los Hijosdalgo la mitad de oficios dellos; pues por las leyes así está ordenado y de justicia y razón se les debe dar», CLC, Cuaderno de Cortes de Madrid de 1579, petición LXIV, tomo V.

37 Alcañabate,1510: «Dise que desde tienpo ynmemorial a esta parte se a husado e acostunbrado en la villa de Alcañavate, asy antes que fuese villa como después que lo es, que todos los que entran en los ofiçios públicos del conçejo avían de ser e an sydo e son honbres pecheros. Que no an de entrar, ni entran, ni an entrado en los ofiçios desde el tienpo ynmemorial acá esento alguno, ni menos honbre fijodalgo. E que nunca an sydo, ni fueron reçebidos a los ofiçios, ni a alguno de ellos, ningún esento ni fijodalgo. Lo qual dieze que sabe porque él es natural de la villa de Alcañavate, e naçido e criado en ella, e porque syenpre a vivido toda su vida en ella. E porque desde que él llego a su hedad para saber acordar e dar razón de las cosas que viese, que sería de dies años hasta agora, que podía aver çinquenta años e es agora de sesenta años, syenpre continamente a visto e sabido aver e que a avido en ay en la villa de Alcañavate el dicho huso e costunbre, e porque nunca desde el tienpo de los çinquenta años acá asy antes que la villa de Alcañavate fuese villa como después que lo es, ha visto ni sabido ni oydo desir que ninguno ni alguno de los esentos e fidalgos entrase en los ofiçios, que fuese reçebido a ellos ni alguno de ellos e que sy lo oviera sydo que él lo oviera visto e sabido", ARChG, Elecciones, Caja 501, pz.5. En Cabeza de Vaca, en 1580, en la probanza del concejo que se opone la mitad de oficios se dice en dos de las preguntas lo siguiente: «Yten, si saben que en tienpos pasados a avido copia de hijosdalgo vezinos de la dicha villa y aviéndola nunca jamás se les a repartido ni dado la mitad de ofiçios del dicho conçejo de Cabeça la Vaca a los hijosdalgo, ny tal horden se a tenido. Antes por provisiones emanadas del Real Consejo de Órdenes y por costunbre antiquísima, de çinco en çinco años, se a fecho pilorio y por él repartido a los vezinos de la dicha villa conforme a la ensaculaçión que el conçejo de la dicha villa 
no sólo innecesaria sino también perjudicial pues hasta entonces, según las argumentaciones de los grupos dominantes de los concejos que veían peligrar su mando, la república había estado siempre en paz y bien gobernada. Gobernada además por aquéllos que más interesados estaban en ella, los pecheros, pues fundamentalmente, a juicio suyo, los concejos trataban situaciones o aspectos que afectaban casi exclusivamente a los hombres llanos -fuesen labradores o caballeros- y no a los nobles, que hasta entonces siempre se habían mantenido al margen de la institución municipal -teoría, la última, que es presentada como derivada del desinterés nobiliario y de la insolidaridad de ese estado con respecto al común de la vecindad. Por último los defensores de la situación preexistente estimaban que con el nuevo sistema se perpetuarían en los asuntos concejiles los poderosos - como si ellos no lo fueran- pero, aún más, unos poderosos inhábiles para gobernar pues sólo ansiaban el poder por su codicia, y poderosos que atacaban no a un grupo privado sino a una institución, a una república y su orden en su totalidad.

Si analizamos detenidamente ambas argumentaciones del todo contrarias, se puede observar su coincidencia, más allá de la simple respuesta lógica a una acusación o alegato que se niega. Coincidencias a modo de justificación que reflejan no sólo la realidad política y jurídica sino también ideológica de un tiempo, de un momento, pero que hunde sus raíces en el medievo y salvo determinadas y puntuales modificaciones se mantiene hasta la modernidad.

Ahora bien, eran pleitos por el poder político y en ellos no se respetaba nada más que la victoria: haciendas, honras, vidas, etc., se jugaban en estos litigios.

La parte ofendida, el concejo, mientras era considerada en Derecho tal, repartía, prendaba, dificultaba cualquier actuación del ofensor, la persecución de movimientos, políticos o económicos, era tanto a nivel local como supralocal y no necesariamente se dirigía a la realización de actuaciones más o menos legales o discutibles como mucho, sino que como partido político utilizaba la ofensa, la difamación, la amenaza sobre vidas y patrimonios, la prisión, etc. Si surtía, a lo largo del contencioso, la desgracia para estos ofendidos de ser declarados como grupo privado y no encarnación del concejo, aunque a veces seguían o lo intentaban utilizando la institución que dominaban, lo habitual, además de debilitarse como parte,

tiene de Su Magestad y ansí lo an visto los testigos ser y pasar por más tienpo de quarenta años y an oydo dezir a sus mayores, sin que los unos ni los otros obiesen bisto repartirse los dichos ofiçios del conçejo de la dicha villa al estado de los Hijosdalgo. Y si otra cosa fuera los testigos lo supieran y no pudiera ser menos que e al a sido y es la pública boz y fama común opinión. Yten, si saben que la dicha villa de Cabeça la Vaca es del partido de Segura de León, cabeça del dicho partido, y saben los testigos que en la dicha villa de Segura se guarda la misma horden y pilorio de çinco en çinco años, por la dicha ensaculaçión y ésta es la misma costunbre del conçejo de Segura y su partido. Y puesto que en años pasados çiertos hijosdalgo pretendieron contravenir la dicha costunbre antigua y que la mitad de ofiçios se diese a los hijosdalgo de la dicha villa de Segura en contradictorio juizio y por sentençias de vista y revista emanada del Real Consejo de Órdenes se declaró no aver lugar a lo que pidieron los hijosdalgo y se pronunçió en fabor de la dicha costunbre y se dio executoria de las dichas sentençias a que los testigos se refieran", ARChG, Probanzas, Caja 9126. 
es que continuasen o incluso incrementaran los medios de defensa totalmente rechazables - pero no sólo propios de la justicia o de los conflictos de la Edad Media y de la Edad Moderna- como la amenaza, la deshonra del otro, etc. ${ }^{38}$.

De lo dicho en modo alguno se puede deducir que el grupo o estado que solicitaba su incorporación al concejo fuese una mísera víctima, pues menos los instrumentos de constreñimiento derivados del dominio concejil de hecho y Derecho, eran practicadas tanto las actividades legítimas propias de un contencioso, aunque quizá no éticamente correctas, lo que es indiferente por lo general, en la realidad, cuando se trata de pleitear y por tanto de ganar. Y discurriendo por la misma senda que los que aquí he llamado ofendidos, practicaron la amenaza, la difamación, etc. Todos, unos y otros, buscando la victoria ante el tribunal pero conjugando elementos propiamente jurídicos y forenses con elementos no jurisdiccionales, elementos, los últimos, que tenían su mayor campo de actuación no ante la Corte sino ante los simples vecinos y la localidad en cuestión que eran los que realmente al fin sufrían la contienda y sus consecuencias ${ }^{39}$.

38 A más de un hidalgo le recordaron ascendencias contaminadas para negar la mitad de oficios, no necesariamente por no ser hidalgos, sino por ser inhábiles para ocupar oficios por las leyes que hablaban de los descendientes de condenados por la Inquisición, por ejemplo. Así el concejo de Membrilla, por una real provisión del presidente y oidores granadinos de 28 de junio de 1567, solicitaba a la inquisición de Murcia que informase sobre algunos de los que pedían la mitad de oficios como hidalgos pues había noticias de que «los dichos Pedro Cañuto y Pedro de Cuartas, que eran dos de las partes contrarias, avían sido presos y el uno de ellos penitençiado por el Santo Ofiçio de la Ynquisiçión de la dicha çibdad de Murçia», ARChG, Registro del Sello, Caja 6049.

${ }_{39}$ Las enemistades no eran sólo entre estados, sino que a veces dentro del mismo las luchas podían ser terribles, así ocurrió cuando los Rodríguez de Vera vieron pleiteada su hidalguía y en virtud de ello su entrada en la mitad de oficios. Aquí el acusador, el difamador es otro hidalgo enemigo de los Vera, llamado Juan de Valcárcel Merino, un testimonio sobre esto, de 1577, es largo pero jugoso y no sólo esclarecedor de las intrigas de los pleitos de mitad de oficios y de la ocupación de cargos civiles o eclesiásticos sino también de la crudeza de los pleitos de hidalguía, de ahí la extensión de lo ahora transcrito: «A la segunda pregunta del dicho ynterrogatorio dixo este testigo que lo que sabe es que avía seis o siete meses, poco más o menos, que estando este testigo en la villa de Hellín, en la plaça de la dicha villa hablando con Juan de Valcárcel del Merino, le dixo a este testigo: piensa vuestro amigo Diego Rodríguez ser vicario. Pues no le caerá ençima porque ya le traygo del Santo Ofiçio de Murçia papeles por donde se dize quién ellos son. Y este testigo le preguntó que qué le podía traher en los dichos papeles e qué conthenían. Y el dicho Juan de Balcárçel le dixo a este testigo que la sentençia de su agüelo, cómo avía sido penitençiado por el Santo Ofiçio de la Ynquisiçión y que ansimismo se acuerda este testigo, que en esta sazón no se acuerda si fue antes que pasase lo que thiene dicho en esta pregunta o después estando este testigo en la çiudad de Granada, encontró en ella al dicho Juan de Balcárçel del Merino que andava en seguimiento de los dichos reçeptores en el pleito que tratan sobre su hidalguía y le dixo a este testigo y como lo encontró le dixo a este testigo: nos sabéis nada como bengo de leher en Amadís de Gaula. Y este testigo le respondió que cómo en aquello gastava el tienpo honbre que andava de pleytos. Y el dicho Juan de Balcárçel respondió que no lo dezía sino porque venía de leher en la provança de los Rodrígues para saber quién ellos heran. $Y$ ansí le dixo a este testigo como los dichos Rodríguez heran de generaçión de judíos y desçendientes del Roday y por otro nonbre el Foday, el qual se avía convertido de judío en christiano y que Sancho Rodríguez el viejo, agüelo de los dichos Bartolomé Rodrígues y sus hermanos avía sido pentençiado por el Santo Ofiçio de la Inquisiçión de Murçia, porque estando un domingo en fiesta un criado suyo salía a oyr misa y que el dicho Sancho Rodríguez le avía preguntado que a dónde yba y que el dicho criado le avía respondido que a oir misa y que el dicho Sancho Rodríguez le avía replicado diziendo quitada y pensáis vos que esta misa y cerimonias que los christianos tienen que es verdad ande ay y que es cosa de burla y que el dicho criado lo avía denunçiado al Sancto Ofiçio e que por aver muerto el dicho criado como murió a cabo de pocos días que por eso no lo avían quemado e avía librado tan bien... Y a lo que este testigo entendió el dicho Juan de 


\section{CONCLUSIONES: LA MITAD DE OFICIOS, DEFINICIÓN Y NATURALEZA}

Éste es trabajo de investigación, este artículo es trabajo y artículo enfenido como titulara una de sus obras don Juan Manuel, y por tanto deberá en cuanto al fondo proseguir la investigación y el análisis y, tanto en cuanto al fondo como a la forma, necesitará igualmente de análisis y averiguamientos de otros.

Los grandes núcleos de población son siempre relevantes para el estudio de la Historia local y aunque puedan servir de modelo y objeto de análisis para el estudioso y, además, aunque en diferentes épocas abrieron perspectivas a seguir por parte de los lugares de menor rango, no es menos cierto que su casuística no siempre coincide con la de las entidades de habitación más extendidas en las épocas medieval y moderna: las medias y pequeñas localidades repartidas por la Corona de Castilla.

La mitad de oficios en Concejos si bien se encuentra presente, según los tiempos, en localidades de muy diversa categoría, desde ciudades de relevancia hasta lugares de pocos vecinos, lo cierto es que donde tuvo mayor aceptación, duración y ejercicio de relieve fue en entidades de mediano y pequeño tamaño y por ello todo este análisis y las siguientes conclusiones tienen siempre presente a este tipo concejil.

Concluyendo ya, como es pertinente se va a afrontar en primera instancia, pues in fine todo el discurso gira alrededor de ella, a la misma mitad de oficios en Concejos desde la concreción de su definición, para desde ella explicarla a través de otras conclusiones, siempre entendida la mitad de oficios concejil como un sujeto histórico inserto en procesos de larga duración.

La mitad de oficios concejil en Castilla es una institución de Derecho público bajomedieval y moderno (Sistema Jurídico de la Recepción del Derecho Común) que afecta a la calidad de los oficiales municipales, consistente en otorgar la mitad de todos los cargos de naturaleza añal y no enajenados, o parte de ellos, y que componen la planta del Concejo, a un grupo social con identidad propia reconocida por el ordenamiento jurídico, convertido en estado, y la otra mitad a otro grupo,

Balcárçel gustava en dezir las dichas palabras contra los susodichos Rodríguez. Y este testigo thiene por çierto que según lo que de él entendió que las dezía e dixo con ánimo de ynjuriar y afrentar a los susodichos y a sus deudos, ansí por lo susodicho como por seguir como sigue con grande ynstançia el pleyto de la hidalguía contra los dichos Rodríguez que está pendiente en la dicha Real Audiençia de Granada. Y este testigo a oydo decir en la dicha villa de Tovarra a personas particulares que de presente no se acuerda de sus nonbres que el dicho Juan de Barcárcer del Merino andava mostrando unos papeles que traía çerrados por la villa de Hellín a muchas personas y dezía que en los dichos papeles traía la sentençia de Sancho Rodrígues el viejo, agüelo de los dichos Rodríguez, que la avía sacado de la Ynquisiçión de la çiudad de Murçia... Y es cosa pública e notoria en la dicha villa de Tovarra y en la de $\mathrm{He}$ llín que los dichos Balcárçeles todos en general por el odio y henemistad que les thienen a los dichos Rodrígues por les ynjuriar y afrentar andan diziendo e publicando que los dichos Rodríguez deçienden de la casta de judíos e que este testigo no los thiene por tales ni an sido ni son tenidos en tal reputaçión sino christianos viejos e gente prinçipal», ARChG, Probanzas, Caja 9126. 
también constituido en estado, y por lo tanto con igual derecho a ostentar la titularidad del resto de los oficios municipales. Otorgamiento que afecta tanto a las estructuras electorales como a la institución municipal en sí.

De la presente definición se decanta en primer lugar que la mitad de oficios en Concejos es algo más que una simple práctica o uso, como la historiografía hasta ahora y por lo general la ha tildado, ya que se constituye en institución de Derecho público que alcanza tal naturaleza plenamente bajo el Sistema Jurídico de la Recepción del Derecho Común en la Corona de Castilla.

No se trata, como por muchos se estima, de un tipo electoral concreto y diferente a otros como la aclamación, el voto, la cooptación, etc., ni menos aún se debe circunscribir a la elección el campo de actuación de la mitad de oficios concejil.

Por último, esta definición conscientemente no adjetiva a ninguno de los grupos que se reparten el poder concejil, pues ni es institución pechera ni nobiliaria, y de ningún modo se puede considerar una institución de Derecho nobiliario castellano, ya que su utilización de hecho y de Derecho estuvo siempre a disposición de grupos sociales locales constituidos en estados, grupos que no necesariamente se resumen en los estados prototípicos: estado de los Buenos Hombres Pecheros y estado de los Hijosdalgo.

Es por tanto una institución de Derecho público que aborda, y es su esencia, el acceso, reparto y disfrute del poder político local de grupos sociales constituidos en estados, no considerados sus integrantes como individualidades sino como conjunto acreedor al derecho de participación política en Concejos.

Tratándose de una institución que atiende al poder político y a su goce o falta de él, ésta se encuentra inserta en la configuración del poder político local que experimentó la Corona de Castilla desde el siglo XI gracias a una larga evolución que posee una serie de líneas generales.

Frente a la común opinión que viene a considerar el siglo XIII como la centuria en donde el poder político concejil castellano es sustraído al conjunto de la población en beneficio de élites que desde entonces gozarán en exclusiva del poder local, los Concejos castellanos desde el siglo XI, cuando menos, como reflejo de la sociedad desigual de la que surgen estarán políticamente dirigidos, de hecho primero y pronto también de Derecho, por aquellos individuos que gocen de mayor potencial económico con respecto a sus convecinos. Una sociedad desigual produce un Derecho desigual. Sería incongruente que el Derecho local castellano del Sistema Jurídico Medieval nacido en una sociedad feudal fuera un Derecho de iguales, por lo que pese a la apariencia igualitaria de éste, el Derecho local casteIlano plasma, genera y regenera desigualdades y dependencias. Situación que encuentra uno de sus ámbitos vitales naturales en la política local, en las relaciones políticas de los miembros de la comunidad de cualquier lugar o villa. Esta realidad encontrará su máxima expresión cuando el ejercicio de la política quede por norma 
o por costumbre indisolublemente ligado a los económicamente poderosos, ya sea en virtud de la exigencia del mantenimiento de caballo y armas, ya sea por la exigencia de una determinada cuantía en renta o en raíces al titular de los oficios concejiles o como indican algunos Fueros más primitivos por la obligación de entregar al señor de la localidad un determinado pecho - un buey u otro animal o dineroal finalizar su mandato, que se entiende honroso y lucrativo, por aquéllos que habían disfrutado los portiellos, etc.

El tipo concejil que genera la repoblación castellana está caracterizado por la concentración de la capacidad política en algunos de los miembros de la comunidad y pese a que su prototipo historiográfico y en parte real sea el concejo cerrado de caballeros, en ningún modo debe entenderse como sinónimo de una tipología concejil de naturaleza nobiliaria. La mayoría de los Concejos de la Corona de Castilla, inclusive los más significados, se encuentran dirigidos por grupos esencialmente villanos hasta casi el siglo XV. De naturaleza pechera como contraposición a la calidad nobiliaria, independientemente de que desde una perspectiva hacendística estos dirigentes y sus familias sean exentos por el propio Derecho local y Regio. Así el concejo castellano y de manera significada los creados al sur del Tajo tienden a conformarse más como estructuras de aspiraciones aristocráticas que nobiliarias. Lo que no impidió la existencia bien fraguada en los siglos XV y XVI, sobre todo en grandes poblaciones, de concejos inicialmente villanos convertidos en nobiliarios y menos impidió que la tipología concejil más extendida en la Corona de Castilla fuese, en esos mismos siglos, la del concejo de labradores cristianoviejos.

Asumida la realidad antecedente concretada en las conclusiones ya expuestas, y desde la concepción de los procesos históricos de larga duración, no se puede admitir que exista sobre el siglo XIII —como normalmente propone la historiografía- una quiebra de los sistemas electorales locales medievales originarios ni menos de la naturaleza del ejercicio político concejil. La sociedad repobladora castellana consagra el binomio poder económico / poder político y en él se fundamentan todas la tipologías electorales y de ámbitos de decisión local inclusive las asambleas vecinales, por lo que fenómenos como la cooptación, las regidurías de designación regia o no, el Concejo cerrado, etc., más que como rupturas de tradiciones o modos anteriores han de entenderse como culminaciones de procesos y potenciadores de evoluciones.

Que la base última y esencial de cualquier poder concejil tanto en el Medievo como en la Edad Moderna residiera en el potencial económico de los capaces políticos exigió unos fundamentos ideológicos que encuentran su mejor defensa en el pensamiento bíblico, desarrollado por padres de la Iglesia y teólogos, que establece la directa relación del bienestar material y la gracia y voluntad divina, entendido así el bienestar como justa y perfecta recompensa a la posesión y ejercicio de determinadas virtudes. Y, lo que es más, desarrollo ideológico que al fin viene a propugnar la necesidad de posesiones materiales para poder ser efectiva y prácticamente virtuoso, como por ejemplo sostendría santo Tomás en su Monarquía. 
Esta corriente de pensamiento aplicado al ámbito político se plasmará en la siguiente conclusión: si el rico es rico por ser virtuoso y por ser rico puede más fácilmente ser virtuoso, el rico es el más apto para dirigir los destinos de la comunidad política. Pero como riqueza perfecta aplicada al poder local ésta no puede ser desmedida sino proporcional a la realidad en donde se ejercerá. Es decir mediana en proporción al conjunto de la sociedad de la Monarquía lo que no implica que sea mediana con respecto al ámbito local concreto en donde se ostenta el poder político.

Esta idea de la riqueza legítima como sinónimo de evidencia de virtudes en su titular y que justifica la ocupación y ejercicio del poder político local estará relacionada directamente e incluso se fundirá con otras teorías explicativas y sostenedoras de las estructuras sociales tales como la de los Tres Órdenes o las concepciones políticas surgidas alrededor de la cristianía vieja castellana. Conjunto ideológico que pese a ser desmentido en buena medida por la práctica no dejó nunca de estar presente en el inconsciente y en el consciente colectivo siendo garante de estructuras políticas y jurídicas tanto durante el Sistema Jurídico Medieval como en el de la Recepción. Y conjunto ideológico que precisamente cuando se crea reuniendo en sí justificaciones diferentes pero no absolutamente dispares facilitará a su vez a nivel local la inflación de las exigencias reclamadas al titular de los portiellos potenciando aún más la concentración de poder y la natural exclusión de muchos de los que hasta entonces habían gozado de él.

A fines de la Edad Media e inicios de la Edad Moderna, siglos XV y XVI, existen en todos los territorios de la Monarquía castellana grupos sociales que o bien han perdido su originaria capacidad política local o que no habiéndola poseído nunca, la desean, pero grupos que están y se sienten injustamente excluidos de su ejercicio gracias a la existencia de los referidos concejos de caballeros, de labradores y en menor número de nobles que han concentrado el poder político local casi hasta el paroxismo. La particularidad de esta situación es que estos grupos, que a nivel interno suelen poseer elementos comunes entre sus miembros con tal trascendencia social que son reconocidos por el Ordenamiento Jurídico, otorgándoles cierta capacidad jurídica a través de su consideración de estado, poseen suficiente fortaleza como para ser tenidas en cuenta sus reclamaciones políticas por parte de los titulares del concejo, fortaleza de estos grupos usualmente no general sino concreta que está basada en sus economías y también en los apoyos que instituciones superiores a lo local y el mismo sistema les facilitan.

Las confrontaciones por el poder político local son esenciales a los concejos medievales y modernos y su germen se encuentra en la misma estructura en que se conforman y en la que persisten evolucionando, y ante ellas el Derecho local público buscó siempre una u otra respuesta. Respuestas que se pueden ejemplificar esencialmente —obviando aquí la violencia - por medio de acuerdos o sentencias arbitrales o incluso por mandamientos y disposiciones de jurisdicciones superiores a la meramente local. Estas pugnas por el goce de la capacidad política plena afectarán a diferentes grupos sociales constituidos en estados, grupos so- 
ciales en su esencia dispares y diversos: conformados por cristianos nuevos de cualquier origen, unos descendientes de mudéjares, otros de moriscos, otros de judíos; otros únicamente integrados por nobles; otros tan sólo por pecheros; grupos formados por todos los privilegiados independientemente del origen de su privilegio —hidalgos, bachilleres, licenciados, doctores, caballeros de linaje, caballeros de privilegio, caballeros villanos-; etc.

Por lo usual las intervenciones que la baja Edad Media castellana ofrece a la problemática que supone que grupos constituidos en Estados exijan su participación política en el Concejo suelen plasmarse en medidas que admitiendo semejante participación poseen una naturaleza restrictiva. No otorgando una capacidad política plena y de suficiente relevancia a los peticionarios sino concreta en tal modo que o bien designa oficios como el de procurador de un determinado estado para un determinado asunto que le afecta sustancialmente o bien da entrada a ese estado a través de un oficio habitual, una alcaldía, una regiduría o una procuraduría, pero cuyo peso específico dentro del concejo queda devaluado ante el mayor número de los demás oficios que además siguen en posesión del estado o grupo de poderosos locales que previamente gozaban en exclusiva del concejo. Sin obviar otros reconocimientos de la capacidad política en inicio más equitativos pero siempre más escasos en la práctica pues los poderosos locales no acostumbraron a ceder gratuitamente ninguna cuota política.

La realidad existente en la mayoría de los concejos castellanos en el siglo XV y también durante el siglo XVI es la de una sociedad en donde los grupos de extracción pechera sean caballeros cuantiosos o labradores dominan los concejos, realidad protegida en virtud del Derecho local y en virtud de, posteriormente inserto este último en lo que vino a denominarse estatutos bajo el Sistema de la Recepción del Derecho Común, de los denominados usos y costumbres locales que no sólo son defendidos a nivel local sino que también tendrán garantes, si así les convenía, en los señores y en la propia Monarquía a través de sus tribunales. Esta circunstancia facilitará que la nobleza, el estado de los Hijosdalgo, termine constituyéndose en uno de los sujetos de la mitad de oficios concejil, seguramente en el sujeto por excelencia y que esto haya llevado a algunos a intuir que la mitad de oficios es propia en exclusiva de nobles.

Los fines del siglo XV con el alumbramiento del Estado moderno suponen el fin de formas de vida, usos y relaciones milenarias o centenarias. Pues si bien todas habían sufrido procesos de mutación paulatinos, sólo algunas llegaron a permanecer durante la Época Moderna bajo nuevas fórmulas, mientras que muchas otras por su misma esencia no pudieron adaptarse a las definitivamente establecidas condiciones de la Modernidad. La nobleza sufre principalmente esta situación de cambios y si bien la sufre en todos sus niveles, como por otra parte es lógico, serán los grupos menos favorecidos de ella los directamente afectados. Los hidalgos que insertos en las relaciones feudovasalláticas y de dependencia han vivido al servicio, de un modo u otro, de las grandes casas, magnates e instituciones señoriales, contemplan cómo sus formas de vida desaparecen ante las nuevas re- 
alidades sociales y políticas que impelen a sus antiguos protectores a prescindir de servidores ya no útiles a sus fines. Y, estos hidalgos, a su vez se ven afectados por el fin práctico de su misma función teórica y en cierto modo real que los justificaba como grupo social relevante al concluir la Reconquista con la toma del reino de Granada. Ante estas circunstancias los hidalgos, si bien esto había ocurrido con anterioridad, son atraídos de manera acelerada e irreversible entre el siglo XV y $\mathrm{XVI}$ hacia los Concejos en donde eran moradores pero no vecinos, desligados ya enteramente o en menor grado de las conexiones señoriales, buscando su propia supervivencia, justificación y progreso en el ejercicio de la capacidad política local inicialmente y, después, en el intento de dominio absoluto de los Concejos hasta ese momento pecheros o villanos.

Los otros sujetos de la mitad de oficios en Concejos, sujetos tanto activos como pasivos, están fundamentalmente conformados por grupos que globalmente pueden ser tildados de pecheros, pero advirtiendo que no por ello se van a enfrentar en la pugna por el poder político exclusivamente a la nobleza, al estado de los Hijosdalgo, sino que esas pugnas se darán también internamente, entre ellos. Conviene destacar dentro de esta categoría pechera a dos individualidades los caballeros villanos y los labradores cristianos viejos. Si la nobleza supo mutar sus funciones con la Modernidad presentándose al fin, pese trasnochados discursos nobiliarios, como la clase que debía regir políticamente la sociedad y aquí la local, la caballería villana o de cuantía con el nacimiento de esa Modernidad y del Estado Moderno y más aún con el fin de la Reconquista y las guerras internas pierde su esencial justificación social en la que residía teóricamente la base de su ocupación del poder político local que se entendía como contraprestación a las obligaciones militares que debía prestar. Por último los labradores cristianoviejos que sí soportarán favorablemente el tránsito de los tiempos y que justifican su poder político en las virtudes y aptitudes derivadas de su condición cristianovieja y de su capacidad económica, en muchos casos deberán ceder parte o enteramente los Concejos frente a los nobles, precisamente justificados los últimos en ser acreedores a mejores y más perfectas virtudes provenientes de su nobleza e hidalguía.

Estas pugnas de poder que se dirimen en los Concejos del siglo XV y XVI, encontrarán como una de las vías posibles de solución la implantación de la mitad de oficios, una vía raramente plasmada gracias al consenso, pues ningún poder desea perder alguna o parte de sus competencias, sino que surgirá y se plasmará preferentemente por vía contenciosa. Ya que si bien es cierto que el sistema ofertará métodos no litigiosos para instituir la mitad de oficios en Concejos a través de mandatos que podían contenerse desde en un simple auto dado por cabezas de partido, corregidores, o justicias de las Órdenes Militares hasta en reales provisiones emanadas del Consejo de Órdenes o mejor aún del Consejo de Castilla, no es menos cierto que raramente estos mandamientos no recibían otra contestación de los perjudicados que la protesta e impugnación y al fin la demanda ante los tribunales. De este modo la usual y más eficaz manera de instituir la mitad de oficios en un concejo fue definitivamente el contencioso jurisdiccional ante los tribunales del Rey. 
La mitad de oficios en Concejos ante el fracaso de los sistemas que pretendían su establecimiento no contencioso y ahora directamente relacionada con los deseos nobiliarios de acaparar poder político a nivel local, refrendados por los procuradores de las ciudades con voto en Cortes, generalmente de origen hidalgo, provocaron que las Cortes solicitaran a la Monarquía reiteradamente durante todo el siglo XVI la entrada de la nobleza en los Concejos y al fin una ley general para toda la Corona de Castilla en que sin lugar a discusión se implantara esta institución en los Concejos dando la mitad de ellos al Estado de los Hijosdalgo. No obstante fue siempre una petición que recibió la simple negación de la Corona, que siempre optó por las respuestas concretas a través de provisiones o de las sentencias de sus tribunales. Esta circunstancia de no existencia de una ley general no implica —como mantuvo Domínguez Ortiz y tras él la historiografía mayoritariamente- que esta institución no poseyera fundamentos jurídicos suficientes y similares a otras instituciones coetáneas tanto de Derecho público como privado. Pues la mitad de oficios en Concejos es una realidad reconocida por el Derecho público, por la Costumbre generalmente admitida -lo que no exige general y detallado cumplimiento en todos los Concejos-, por las normas locales que durante el Medievo instauran la mitad de oficios concejil y por fin por normas de naturaleza territorial regia que la contemplaban y no para la Hermandad sino específicamente para los Concejos como se establecen en las recopilaciones de las leyes y normas de las Órdenes Militares del siglo XVI.

La implantación de la mitad de oficios concejil que se presentó como remedio a las conflictos continuos que se repetían en casi todos los concejos de la Corona de Castilla y que además no sólo se consideró óptima - por sus defensores-por el reparto de poder que representaba, sino igualmente porque gracias a ella dirigían la Comunidad los más aptos y virtuosos, nunca supuso el fin de estos conflictos. Los opositores a su implantación una vez asumida ésta, utilizaron gran número de eficaces recursos para estorbar sus efectos ${ }^{40}$, pues aunque vencidos en litigio frente a los jueces seguían siendo poderosos locales con instrumentos suficientes para que en la cotidianeidad municipal no impusieran en más de una ocasión sus decisiones, incluso a veces consiguieron de la Corona, previo servicio económico, la supresión o suspensión de su aplicación ${ }^{41}$. Pues la Corona aunque

40 La conflictividad social entre pecheros e hidalgos es patente y se mantiene más allá de la implantación de la mitad de oficios, evidenciándose a cualquier paso, por nimia que sea la circunstancia, que los pecheros poderosos no dejaban escapar ninguna oportunidad. En 30 de junio de 1581 se pasaba a consulta lo siguiente: «Pedro Ruiz de Caravias, en nonbre de los regidores y procuradores del estado de los Buenos Hombres de la villa de Cuéllar, dize que el arzobispo don Gómez de Cuéllar fundó un hospital en aquella villa y nombró por patronos a los regidores y procuradores del regimiento y, contra lo por él ordenando, los regidores del estado de los Hijosdalgo en las cuentas que toman dos vezes al año gastan excesivamente en comidas y colaçiones y en dexar de asistir más personas de los que deverían conforme a los estatutos. Pide provisión para que no se hagan los dichos gastos ni a las quentas se hallen más personas de las que el fundador mandó por su estatutos. Infórmese», AHN, Consejos, Leg. 7046.

${ }_{41}$ Muestra, una más, de las fluctuaciones que sufría a veces, la mitad de oficios ganada, desapareciendo su práctica gracias a las actuaciones de los que habían perdido el pleito pero que seguían siendo poderosos en sus villas, es el testimonio dado por un labrador de Villanueva de la Serena, Juan Ruiz, de 60 años, a mediados del siglo XVI: «el conçejo del lugar de Don Benito a estado y está en posesión, 
teórica garante de la nobleza de Castilla, sometida ésta a sus designios, incluso en cuanto a su reconocimiento único por medio de los pleitos de hidalguía, no deseó otorgar nunca tamaño poder de forma difícilmente atacable a la nobleza y menos aún a grupos no nobiliarios como los cristianos viejos o los llamados a la extinción caballeros de cuantía, manteniendo siempre la regia posición de árbitro — parcial— pero árbitro al fin entre los Estados que se disputaron el poder concejil en Castilla.

\section{APÉNDICE DOCUMENTAL}

\section{Documento 1.}

1490, abril, 4

Real provisión dada por los Reyes Católicos en Sevilla confirmando los privilegios, usos y costumbres de Arjona que se pretendían modificar en un pleito de mitad de oficios.

\section{ARCHG, Elecciones, Caja 2200 pz.5}

Don Fernando e doña Ysabel, por la graçia de Dios, rey e reyna de Castilla, de León, de Aragón, de Çeçilia, de Toledo, de Valençia, de Galizia, de Sevilla, de Córdova, de Córçega, de Murçia, de Jaén, de los Algarves, de Algezira, de Gibraltar, conde y condesa de Barçelona, señores de Vizcaya e de Molina, duques de Athenas y de Neopatria, condes de Ruysellón y de Çerdanía, marqueses de Oristán e de Goçiano, al prínçipe don Juan, nuestro muy caro e muy amado hijo, e a los ynfantes, duques, per-/lados, condes, marqueses, ricos honbres, maestres de las Hórdenes, alcaides de los castillos e casas fuertes e llanas, e los del nuestro Consejo, alcaldes e otras justiçias qualesquier, de la nuestra Casa e Corte e Chançillería, etc., e al que es o fuere nuestro governador del maestrazgo de $\mathrm{Ca}$ latrava e a sus lugarestenientes en las villas y lugares que la dicha horden tiene en el obispado de Jaén e a cada uno e qualesquier de vos que agora son o serán de aquí adelante e a quien ésta nuestra carta fuere mostrada o su traslado de ella sinado de escrivano público, salud y graçia.

Sepades que el conçejo, alcaldes, alguaziles, regidores, cavalleros, escuderos, ofiçiales e omes buenos de la villa de Arjona, que es de la dicha Horden de Calatrava nos fizo relaçión por su petiçión diziendo que la dicha villa e los veçinos e moradores de ella tienen çiertos previlegios e usos e costunbres que les an sido guardados e confirmados por los reyes de gloryosa memoria, nuestros progenitores, e por los maestres que hasta aquí an sido de la dicha Orden, por ende que nos suplicavan e pe-

uso y derecho e costumbre de dar todos los ofiçios de conçejo a los onbres labradores llanos ricos y honrados y de buena vida y fama, e que no se davan ni dan los dichos ofiçios de conçejo a hijosdalgo ninguno, salvo la una vara de la Hermandad. E esto que puede aver veynte e ocho años, por más o menos, que este testigo vido que çierto tienpo que no sabe quanto fue, tuvieron la mitad de ofiçios del conçejo los hijosdalgo y la mitad los pecheros y después se los quitaron e no se los an dado otra ninguna vez los dichos ofiçios a los dichos hijosdalgo", ARChG, Hidalguía, Caja 5084, pz. 5. 
dían por merçed que les mandásemos guardar y confirmar los dichos sus previlegios e buenos usos e costunbres que la dicha villa tiene o como la nuestra merçed fuese.

Lo qual por nos visto tuvísmolo por bien. Por ende que vos mandamos a todos y a / cada uno de vos que veades los dichos previlegios e buenos usos e costunbres que la dicha villa de Arjona e los veçinos e moradores de ella tienen e ge los guardadedes e cunplades e fagades guardar y cunplir en todo y por todo, asy e según que hasta aquí les han sido usados y guardados e que contra el thenor e forma de ellos les non vayades ni pasedes nin consintades yr ni pasar en tienpo alguno ni por alguna manera.

E los unos ni los otros no hagades ni hagan ende al so pena de la nuestra merçed e de diez mil maravedís para la nuestra Cámara a cada uno que lo contrario fiziere.

E demás mandamos al ome que vos enplaze que parescades anthe nos en la nuestra Corte do quyer que nos seamos, del día que vos enplazare fasta quinze días primeros siguientes, so la dicha pena, so la qual mandamos a qualquier escrivano público que para esto fuese llamado que dende al que vos la mostrare testimonio sinado con su sino porque nos sepamos en como se cunple nuestro mandado. Dada en la muy noble çibdad de Sevilla a quatro días del mes de abril, año del naçimiento del nuestro salvador Ihesu Christo de mil e quatroçientos e noventa años. Yo el rey. Yo la reyna. Yo Fernad Álvarez de Toledo, secretario del rey e de la reyna, nuestros señores, la fize escrevir por su mandado.

\section{Documento 2}

1492, junio, 24

Elecciones realizadas en la villa de Utrera según su uso y costumbre inmemorial. ARChG, Elecciones, Caja 682, pz.11

Domingo, veintiquatro días del mes de junio de mil e quatroçientos e noventa e dos años.

En este día se ayuntaron en la casa de Cabildo de esta villa, Françisco Martín de Dahorco e Alonso Ramos, alcaldes, e Martín Ximenes, alguazil, e Diego Martín de Vegines, mayordomo / e Diego Martín Cordero, Mateo Sanches Amigo, Fernando Ruiz Nyeto, regidores e Rodrigo de Arcos.

En este día se escribieron quatro nonbres para alcaldes, para dos años, dos nonbres para alguasiles, e dos nonbres para mayordomos, e dies y seis nonbres para regidores e se echaron en un bonete prieto doblado del alcalde Françisco Martín. E llamaron a un niño el qual sacó del dicho bonete cada papel de cada nonbre por sí e sacó para alcaldes e alguazil e mayordomo e regidores estos siguientes: 
Pero Garçía de Xerez e Juan de Ribas, alcaldes.

Diego Ximénez, alguazil.

Antón Ruis Cordero el moço, mayordomo.

Regidores:

Bartolomé Garçía Rascado

Fernán Gonzales de Lebrixa

Andrés Martín de Coria

Fernando Moreno

Diego Fernandes Gómez Cerdena

Pero Ximenes, hijo de Diego Ximénez

Pedro de Coria

Benito Martín Parexo /

Eligieron para alcaldes de la Hermandad a Juan Dias de la Puebla e a Juan Martín Pastor.

Domingo, quinze días del mes de julio de noventa e dos años.

En este cabildo de esta villa ayuntados según lo avemos de costunbre, Françisco Martín de Cadahorco, alcalde, e Martín Ximenes, alguazil, e Pero Garçía de Xerez e Juan de Ribas, alcaldes, e Diego Ximenes, alguazil, e Antón Ruiz, mayordomo, e Diego Martín Cardero e Bartolomé Garçía Rascado, Benito Martín Parejo, e Diego Fernández Gómez Cardena, Alonso Martín de Vegines, Fernán Gonçales de Lebrixa e Fernán Pérez Moreno e Andrés Martín de Coria e Juan Montes de Oca e Juan Martín Gordillo.

En este cabildo paresçieron Pero Garçía de Xeres e Juan de Ribas e presentaron la confirmaçión de sus ofiçios de alcaldes, e Diego Ximénez presentó su confirmaçión de su alguazilalgo, los quales dichos alcaldes e alguazil juraron en forma de Derecho de guardar el serviçio de los reyes nuestros señores y de Sebilla e el bien / e pro común de esta villa e quedó que no usen fasta que vayan a los mojones.

En este día se juraron el mayordomo Antón Ruys Calero e Fernán Gonçales de Lebrixa e Benyto Martín Parejo e Fernando Peres Moreno e Bartolomé Garçía Rascado e Juan de Coria e Diego Fernandes Gomes Cardeña, regidores, en forma de Derecho.

Hordenaron e mandaron que mañana lunes por la mañana, los ofiçiales viejos e regidores e los nuevos vayan a los mojones e los fagan según la carta de los alcaldes mayores lo manda. E mandaron al dicho mayordomo que lleve lo que es menester e cojan ocho onbres sus çerones e espuertas, etc. 


\section{Documento 3}

1493, septiembre, 26

Real provisión de los Reyes Católicos para que se realicen probanzas en Alcázar de Consuegra en el pleito que existe en apelación ante el Consejo Real, para que el concejo de dicha villa admita en los oficios a los hidalgos y mercaderes.

AGS, Registro General del Sello, 1493, septiembre, fol.48

Don Fernando e doña Ysabel, etc. a vos el bachiller Juan de Medina, salud e graçia. Sepades que pleito está pendiente ante nos en el nuestro Consejo en grado de apelaçión de una sentençia dada por el prior de sant Juan, entre partes: de la una los fijosdalgo e mercaderes de la villa de Alcáçar de Consuegra; e de la otra los onbres buenos pecheros de la dicha villa e los alcaldes e regidores de ella; e sus procuradores en sus nonbres. Sobre rasón que por una carta en nonbre del conçejo, justiçia, regidores, ofiçiales e omes buenos de la dicha villa de Alcáçar, presentó ante nos en el nuestro Consejo una petiçión e un proçeso de pleito por la qual dixo, que en el dicho nonbre se presentava ante nos en grado de apelaçión, agravio e nulidad, en aquella mejor forma que podía e de derecho devía de una sentençia dada e pronunçiada por el prior de Sant Joan, por virtud de una nuestra çédula, entre los dichos sus partes e otros vesinos de la dicha villa que se desían hidalgos y esentos. Por la qual dicha sentençia el dicho procurador diz que avía declarado que el uno ofiçio de alcaldía de la dicha villa se devía dar en cada un año a los dichos hidalgos y esentos e una de las dos fieldades a los mercaderes e los otros ofiçios de regimientos los repartiesen en çierta manera contenida en la dicha sentençia. Lo qual dixo ser ninguna e de alguna contra los dichos sus partes muy ynjusta e agraviada por muchas razones, que en la dicha su petiçión dixo e alegó por las quales nos suplicó que mandásemos revocar la dicha sentençia e condenar en costas a las partes contrarias. Contra lo qual fue respondido por Diego Lópes de Perea, por sy e en nonbre de los otros cavalleros e onbres fijosdalgo e mercaderes, veçinos e moradores de la dicha villa de Alcáçar, por otra petiçión que ante nos en el nuestro Consejo presentó. En que dixo que la dicha sentençia era pasada en cosa juzgada e de ella no avía sydo apelado dentro del término puesto, ni se avía presentado la dicha apelaçión e presentado según e como de Derecho devían e heran tenidos. Ya que ella fue y es conforme a la comisyón de delegaçión por nos al dicho prior fecha, por las dichas razones e por otras muchas que en la dicha su petiçión dixo e allegó, nos suplicó proveyésemos la sentençia ser justa e derechamente dada e syn enbargo de lo contra ella dicho la devíamos confirmar.

Sobre lo qual por amas las dichas partes fueron / dichas e alegadas çiertas razones por sus petiçiones que ante nos en el nuestro Consejo presentaron fasta tanto que concluyeron. E por los del nuestro Consejo fue avido el dicho pleito por concluso e dieron en él sentençia en que fallaron que el prior de Sant Joan, que de este pleito conosçió por virtud de una nuestra çédula, que la sentençia que él dio que hera agraviada e diéronla e pronunçiáronla por ninguna e revocáronla en 
quanto de fuero pasó e viniendo al negoçio prinçipal, faziendo en ello que derecho se devía faser, fallaron que devían reçebir e reçibían a amas las dichas partes conjuntamente a la prueva de todo lo por ellas e cada una de ellas dicho e alegado, asy ante el dicho prior como ante ellos e que de Derecho devían ser reçevidos a prueva e provado les aprovecharía, salvo iure yntepertinençiun ey non atmitendorum, para la qual prueva faser e para la traher e presentar ante ellos les dieron e asygnaron término de quarenta días primeros siguientes con çierto apreçebimiento. Después de lo qual el dicho procurador en el dicho nonbre paresçió ante nos en el nuestro Consejo e dixo que los testigos de los dichos sus partes se entendían aprovechar heran y estavan y bivían en las villas e lugares del dicho prioradgo de San Juan e por ende nos suplicava e pedía por merçed le mandásemos dar un reçebtor que hisese la dicha provança o como la nuestra merçed fuese. E nos tovímoslo por bien e confiando de vos que soys tal que guardaredes nuestro serviçio e la justiçia de las partes e bien y fielmente fareis lo que por nos vos fue encomendado e cometydo. E acordado que vos devíades cometer la dicha reçebçión de los dichos testigos e que por quanto el procurador de los dichos hidalgos e mercaderes no estavan en nuestra Corte para le notificar el dicho término que devíamos mandar dar esta nuestra carta en la dicha rasón.

Porque vos mandamos que ante todas cosas notifiquéis esta nuestra carta al procurador de los fidalgos e mercaderes para que dentro del dicho término de los dichos quarenta días por virtud de ella, syn otra carta de reçevtoría puedan faser su provança sy quisieren e asy notificada, seyendo requerido por qualquier de las dichas partes dentro del dicho término de los dichos quantenta días en la dicha sentençia contenidos, los quales mandamos que corran e se cuenten desde el día que con ésta nuestra carta vos el dicho bachiller fuéredes requerido, fagáys paresçer ante vos los testigos que vos nonbraren. $\mathrm{E}$ a asy paresçidos tomedes e reçebades de ellos e de cada uno de ellos juramento en forma devida de Derecho e sus dichos e depusyçiones, secreta e aparatadamente a cada uno de ellos sobre sy, preguntándoles por ynterrogatorio que por qualquiera de las dichas partes vos fuere presentado. E a lo que los dichos testigos e cada uno de ellos dixeren que sabe lo contenido en la pregunta syguiente sea preguntado cómo e por qué lo sabe e a lo que dixeren que lo oyeron, sean preguntados a quién lo oyeron e quanto tienpo fase. E a lo que dixieren lo creen, sean preguntados cómo e por qué lo creen. Por manera que cada uno de los dichos testigos den rasón legítima de sus dichos e depusyçiones e lo que asy los dichos testigos dixeren e depusyeren, lo fagáys escrivir en linpio e firmado de vuestro nonbre e sy-/nado del escrivano ante quien pasare. E çerrado e sellado en pública forma en manera que haga fe lo dad e entregad a qualquier de las dichas partes que hisieren la dicha provança para que lo traygan e presenten ante nos para guarda de su derecho. Pagando prinçipalmente al escrivano su justo e devido salario que por ello oviere de aver. E mandamos a los dichos testigos e a cada uno de ellos que vengan e paresçan ante vos a vuestros llamamientos e enplasamientos en los plasos e so las penas que de nuestra partes le pusyéredes, las quales nos por la presente les ponemos e avemos por puestas. 
Para lo qual todo con sus ynçidençias e dependençias, anexidades e conexidades vos damos poder conplido por ésta nuestra carta.

Es nuestra merçed que ayades de salario para vuestra costa e mantenimiento cada uno de los días que en esto os ocupades dosientos e treynta maravedís e para un escrivano que con vos vaya, ante quien pase la dicha provança, cada uno de los dichos días que en esto ocupáredes setenta maravedís demás e allende de las presentaçiones de los testigos y escripturas e otros abtos que el dicho deviere e oviere de aver. Los quales mandamientos que ayades e cobredes e vos sean dados e pagados por amas partes cada una al tienpo que ocupare. Para los quales aver e cobrar e para faser sobre ello las prendas, prisyones e vençiones e remates de bienes que nesçesarias e conplideras se an de se faser vos damos asymismo poder conplido por ésta nuestra carta e non fagades ende al.

Dada en la çibdad de Barçelona a 26 días de setienbre de mil e quatroçientos e noventa e tres alos. Don Álvaro. Johannes dotor, Antonius dotor, Françicus liçençiatus Petruque dotor. Yo Christóval de Bitoria, escrivano de Cámara del Rey e de la Reyna nuestros señores la fiz escrivir por su mandado con acuerdo de los del su Consejo.

\section{Documento 4}

1496, abril, 9

Real provisión del Consejo dada en nombre de los Reyes Católicos por la que se comisiona a Fernán Gómez de Solís para que resuelva el litigio que enfrentaba al concejo de Villanueva y sus pecheros con los hidalgos sobre los oficios y su entrada en ellos.

AGS, Registro General del Sello, 1496 abril, fol. 127.

Don Fernando e doña Ysabel, etc., a vos Fernán Gomes de Solys, nuestro vasallo, salud e graçia.

Sepades que por parte de los cavalleros e fydalgos, veçinos de Villanueva, nos fue fecha relaçión, etc., dyziendo que los hofyçios de alcaldes e regydores e otros ofyçios públycos de la dicha villa se reparten entresy los labradores e omes buenos pecheros de ella, e que a los dichos cavalleros e ydalgos non dan ni se reparten ningunos de los dichos ofyçios. Repartyéndolos los dichos ofyçios entre todos los lugares comarcanos de la dicha villa entre los cavalleros e ydalgos e pecheros. A causa de los qual diz que la nuestra justyçia de la dicha villa no está byen regyda ni adminystrada como deve e que en ello los dichos cavalleros e ydalgos veçinos de ella reçiben mucho agravio e daño e en su nonbre nos fue suplycado e pedydo por merçed que sobre ello les proveyésemos de remedio con justyçia, mandando que los dichos ofyçios de alcaldes e regydores e los otros ofyçios públicos de la dicha villa se repartyesen en cada un año entre todos los cavalleros e 
ydalgos e pecheros, veçinos de la dicha villa segund que se faze en los otros lugares, sus comarcanos, o como la nuestra merçed fuese.

E nos tovímoslo por byen porque vos mandamos que luego veades lo susodicho e llamadas e oydas las partes que quien atañe, libredes e determinedes sobre ello lo que falláredes por fuero e por Derecho por vuestra sentençia o sentençias, ansy ynterlocutoryas como defynitivas. La qual y las quales y el mandamiento / o mandamientos que sobre la dicha razón dyñeredes e pronunçiáredes llevedes e fagades levar pura e devida esecuçión con efeto quanto e como con fuero e con Derecho devades.

E mandamos a las partes a quien lo susodicho atañe e a otras qualesquier personas a quien los susodicho entendyéredes ser ynformado e mejor saber la verdad de ello que vengan e parescan ante vos a vuestros mandamientos e enplazamientos e a los plazos e so las penas que vos de nuestra parte les pusyéredes e enbyáredes poner, las quales nos por la presente les ponemos a avemos por puestas.

Por lo qual todo lo dicho es, ansy fazer e cunplyr, vos damos poder conplydo por ésta nuestra carta con todas sus ynçidençias e dependençias, anexidades e conexidades.

E non fagades ende al.

Dada en Valladolid a diez e nueve días de abryl de noventa e seys años. Joepus Astoriaceno. Johannes dotor, Antonius dotor (Sic) e yo Alfonso del Marmos, etc.

\section{Documento 5}

\section{7}

Escrito de contestación a la demanda realizado por parte del procurador del concejo y hombres buenos de Madridejos, negando la demanda de mitad de oficios requerida por los hidalgos de ese lugar.

ARCHG, Elecciones, Caja 5027, pz. 18

Virtuoso señor liçençiado de Cuellar, juez comisionado por el muy magnyfico señor el prior de Sant Juan, nuestro señor. Yo Cristóval de Mora, en nonbre e como procurador que soy del Conçejo, Justiçia, Regidores del lugar de Madridejos, respondiendo / a una demanda ante vos presentada por Garçía de Cogollos, por sy y en nonbre como procurador que se dixo ser de Fernand López de Çervantes e Lope Yañes e Diego López de Çervantes e Mayorga e Taguada e Diego Vasques e de los otros que dyse hydalgos en el dicho lugar, en que confesó, dixo e relató que él e los dichos sus / partes les avyan requerido muchas vezes a los alcaldes e ofiçiales del dicho lugar les, diesen parte de los ofiçios e alcaldyas del dicho lugar, pues que heran personas ávyles para usar e exerçer los dichos ofiçios del dicho lugar e que los dichos mis partes no se los avyan querido dar. Pydyo a vuestra 
merçed / que los condenase segund que más largamente en la dicha su demanda se contyene, sobre lo qual fizo su justiçia e su devido pedymiento, el tenor del qual avido aquí por repetido, digo que los dichos mis partes no son tenudos ni obligados a fazer ni complir / cosa alguna de lo en contrario pedido por lo syguiente:

Lo primero, por defeto de parte que el dicho Garçía de Cogollos nin los que dixo sus partes, no es ninguna para pedyr ni demandar cosa alguna de los en contrario pedido e demandado ni algunos de los dichos partes / contrarios son fidalgos nin en tal posesyón los tiene el conçejo del dicho lugar en el padrón de los pecheros están enpadronados, pues que en esto el conçejo tyene fundada su yntinçión de Derecho como fasta que algunos de los partes contrarias mostrasen e provasen sus hydalguias / ante quien e como devyesen, no serían ni son partes para pedyr como tales fidalgos los dichos ofiçios.

Lo otro porque puestos que lo fuesen, menos pueden pedyr los dichos ofiçios y pydiéndolos por él ninguno fecho, segund Derecho non deven ser admitydos porque pareçería aver los tales / ofiçios por anbiçión, la qual es defendida en los ofiçios públicos y el dicho conçejo mis partes cada año segund el uso e costunbre inmemorial del dicho lugar y ende los otros lugares de estos reynos, segund Dios e sus conçençias el juramento que sobre ello primero fazen alcaldes regydores / e otros ofiçiales, aquellos que segund Dios e sus conçençias les pareçe que son ábiles e sufiçientes para regir e governar el pueblo, contra lo qual pues es a sus conçiençias e juramento es dexado, no se podría refriçar quistyón ni contradezir-/se e ansy mediante dyspusyçión de Derecho ningund fidalgo de Derecho non pudo nin puede dezir por qué non me nonbrasteis por alcalde o por regidor e ay digo que los susodichos non son nin pueden ser partes nin demandar los tales ofiçios ni los / puedan nin devan dar.

Otro, porque el remedyo y açión por ellos yntentada ni la conpetió nin conpete ni aquel es intentado nin en tienpo nin en forma, antes sería y es prescrito por descargo de tanto tienpo que puesto que algunas açiones les conpetían, aquella sería e fue estinto.

Otro la dicha su demanda es horada / ynheta e mal formada e careçiente de las cosas sustançiales que en el Derecho se requiere.

Lo otro porque es ynçierta e no tal e oscura, sobre la qual çierto ni efecto justo se puede dar nin fundar.

Lo otro porque la relaçión de ella no fue ni es verdadera, e niégola en el dicho nonbre segund / e como en ella se contiene con ánimo de contestar e contestándola digo que puesto que el dicho uso e costunbre en contrario alegado fuese verdadero, lo que no se provará, aquél se entendería e entiende en la çiudades e villas donde ay mero y misto ynperio y aunque entonçes no los pidiendo los ofiçios los dichos fidalgos, más en las aldeas / que están sujetas a las villas como el dicho lugar de Madridejos, sugeto a la villa de Consuegra, no se entendería nin entiende en que esté como como está la juridiçión pedania como porque en la dicha villa de 
Consuegra no ay debate nin pendençia sobre los dichos ofiçios nin jamás lo uvo y si dizen las partes contrarias que allí ay alcalde / fijodalgo e que él tiene juridiçión en el dicho lugar Madridejos tanbién como en la dicha villa de Consuegra, en la qual dicha villa no tienen parte de otros ofiçios salvo alcaldía. E asy digo que puesto que oviesen de ser admitidos al dicho ofiçio y tal uso e costunbre ovyese en las otras çibdades e villas / de estos reynos no lo avría ni lo ay en las aldeas ni nadie lo vydo y enpareçiendo cosa fea demandar ofiçio al fidalgo pedanio que repone a la nobleza de su fidalguya. Por las quales razones e por cada una de ellas e por otras que sy neçesario es / que se dirán e alegarán e fallaréys, señor, los susodichos no ser partes nin su demanda proçeder ni aver lugar y ansí lo pido pronunçiar e declarar asolviendo a los dichos mis partes e a mí en su nonbre de la ynstançia de vuestro juizio y de esto çese los asolváys e déys por libres e quitos / de todo lo contrario pedido e demandado, poniéndoles sobre todo ello sylençio perpetuo para lo qual en lo neçesario, conplidero al muy honrado ofiçio de vuestra merçed ynploro y pido e protesto las costas. El bachiller de Lillo

\section{Documento 6}

1511, febrero, 18

Sentencia de los oidores de Granada por la que se ordena al concejo de Alcañabate que no impida que ciertos hidalgos puedan ser oficiales del concejo.

ARChG, Elecciones, Caja 501, pz.5

En el pleyto que es entre Rodrigo Pacheco e Andrés de Alarcón e de Juan de Alarcón e Alonso de Lara e Gómez de / Peralta e Juan de Rabe e Diego de Castañeda e Arias de Tévar e Juan del Canpo e Martín de la Serna e Bernaldino / Lópe e Pedro de Lomas e Juan de Gavaldón, vesinos de la villa de Alcañavate e su procurador en su nonbre de la una parte, e el / conçejo, justiçia, regidores, ofiçiales e omes buenos de la dicha villa de Alcañavate e su procurador en su nonbre de la otra. / Fallamos que la parte de los dichos Rodrigo Pacheco e Andrés de Alarcón e Juan de Alarcón e los otros sus consortes provó bien e conpli-/damente su yntinçión e demanda e todo aquello que provar devían e les convenía e damos e pronunçiamos su yntynción / e demanda por bien e conplidamente provada e que la parte de la dicha villa de Alcañavate no provó sus exençiones e defensyones / ni cosa alguna que les aproveche e damos e pronunçiamos su yntynçión por no provada. Por ende que devemos mandar e / mandamos a la dicha villa de Alcañavate e vesinos e moradores de ella que agora e de aquí adelante e en todo tyenpo / admitan e resçiban a los dichos Rodrigo Pacheco e Andrés de Alarcón e Juan de Alarcón e a los otros sus consortes al hechar de / las suertes de alcaldes e regidores e otros ofiçios públicos de la dicha villa e que ge los dexen e consyentan administrar / e exeçer por el tyenpo e tyenpos que les cupiere por las dichas suertes, libre e desenbargadamente, syn contradi-/çión alguna, sopena de veynt mil maravedís para la Cámara de la Reyna nuestra señora por cada vez que contra ello / fueren e pasaren e tentaren de yr e pasar. E por algu- 
nas cabsas e rasones que a ello nos mueven no fazemos con-/denaçión de costas contra ninguna ni alguna de las dicha partes. Más mandámosles que cada una de ellas se pare a las que / a hecho.E por esta nuestra sentençia difinitiva, juzgando, ansy lo pronunçiamos e mandamos en el escriptos e por ellos./

Martínes, doctor (Firmado y rubricado)

Liçençiatus Guerrero (Firmado y rubricado)

Liçençiatus de la Corte (Firmado y rubricado)

Liçençiatus Gutiérrez (Firmado y rubricado) /

Dada e rezada fue esta sentençia por los señores oydores de la Abdiençia de la Reyna, nuestra señora, que en ella firmaron sus nonbres / en la çibdad de Granada. Estando fasiendo abdençia pública, martes a diez e ocho días del mes de hebrero de mil e quinientos / e honze años. Estando presentes Andrés Lopes de Valladolid e Alonso Alvares de Villarreal, procuradores de anbas las dichas partes.

\section{Documento 7}

1520, septiembre, 5

Real provisión ordinaria dada en nombre de Carlos y Juana por el presidente y oidores de Granada para que se guarden las leyes que versan sobre los privilegios de los hidalgos y sus deudas. Fue dada en favor de Martín de Vera, vecino de Gran Canaria.

ARChG, Registro del Sello, Caja 5531.

Don Carlos e doña Juana, su madre, etc, a todos los corregidores, asistentes, governadores, jueses e alcaldes e otros jueses e justiçias qualesquier asy de la ysla de la Gran Canaria, como de todas las otras çibdades, villas e lugares de estos nuestros reynos e señoríos que agora son e serán de aquí adelante, e a cada uno e qualesquier de vos en vuestros lugares e jurediçiones a quien ésta nuestra carta fuere mostrada, salud e graçia.

Sepades que Juan de Medrano, procurador de cabsas en la nuestra Audiençia, en nonbre de Martín de Vera, veçino de la dicha ysla de la Gran Canaria, nos hizo relaçión por su petiçión que en la nuestra Audiençia que está e reside en la çibdad de Granada, ante el presidente e oydores de la nuestra Audiençia presentó por la qual en efeto dixo, que syendo el dicho su parte onbre hijodalgo notorio de padre e agüelo e de vengar quinientos sueldos segund fuero de España y estando y aviendo estado él e el dicho su padre e su ahuelo en tal posesyón de tienpo ynmemorial a esta parte, se temía e reçelava que las justiçias de la dicha ysla de la Gran Canaria e de las otras çibdades, villas e logares de estos dichos nuestros reynos e señorios a pedimiento / de algunas personas que al dicho su parte pedían debdas, le prendarían su persona e las otras cosas que las leyes de 
los dichos nuestros reynos mandavan que fuesen libres e que no fuesen tomadas a los omes fijosdalgo por debdas.

Por manera que nos pedía e suplicava mandásemos dar al dicho su parte nuestra carta e provisión real, ynserta en ella las leyes de nuestros reynos que mandavan que los omes hijosdalgo e sus cosas no fuesen presos por debdas e sobre ello le proveyésemos de remedio con justiçia o como la nuestra merçed fuese.

E por los dichos nuestros presidente e oydores visto lo susodicho, por quanto el señor Rey don Alonso e el Rey e la Reyna don Fernando e doña Ysabel, de gloriosa memoria, nuestros señores padres e agüelos, hordenaron e hizieron çerca de lo susodicho dos leyes, su thenor de las quales, una en pos de otra, es e son que se sygue:

Ordenamos que ningún hijodalgo pueda ser preso ni encarrçelado por debda que deva, salvo sy no fuere arrendador o cogedor de nuestros pechos e derechos, porque en tal caso, él mismo quebranta su libertad para sí mismo. Mandamos que ningund fijodalgo pueda ser puesto a tormento porque antiguamente les fue asy otorgado por fuero. Porque las leyes de suso contenydas son justas / e razonables e porque deven ser favoresçidos los hijosdalgo por los reyes, pues con ellos fazen sus conquistas e de ellos se syrven en tienpo de paz e de guerra e por su consyderaçión les fueron dados previlexios e libertades, espeçialmente por las leyes suso contenidas, las quales confirmamos e mandamos que los hijosdalgo no sean puestos a quystión de tormento ni les sean tenudos por debdas sus armas e cavallos ni que sean presos por debdas, salbo en los casos susodichos que los derechos ponen. E mandamos que las dichas leyes sean guardadas se aquí adelante.

E fue por ellos acordado que devíamos mandar dar ésta nuestra carta en la dicha razón, e nos tuvymoslo por bien.

Por la qual mandamos a vos las dichas justiçias e a cada una de vos en vuestra jurediçión, que veáys la dicha ley que de suso en ésta nuestra carta va encorporada e lo en ella contenido. E la guardéys e cunpláys e hagáys guardar e cunplir en todo e por todo, segund e como en ella se contiene.

E contra el the-/nor e forma de ella ni de lo en ella conthenido no vayáis ni paséys ni consintáis yr ni pasar por alguna manera, ny cabsa, ny raçón que sea so las penas en la dicha nuestra ley conthenidas e más so pena de la nuestra merçed e de otros diez mil maravedís para la nuestra Cámara e de a cada uno de vos por quien finare asy faser e cunplir. E demás mandamos al ome, etc. años.

Dada en la çibdad de Granada a çinco días del mes de setienbre de 520

Libráronla el liçençiado de Toro e los dotores de Luna e Escudero. 


\section{Documento 8}

1540, noviembre, 19

Extracto de la concordia, acuerdo y apoderamiento entre los hidalgos de Cazorla para iniciar un pleito de mitad de oficios contra los caballeros de cuantía que hasta entonces dominaban el concejo.

ARChG, Hidalguía, Caja 136, pz. 21

Primeramente dezimos nos, todos los que de yuso seremos nonbrados y declarados, que queremos y es nuestro boto y paresçer que el dicho pleito de los dichos ofiçios de conçejo se siga y trate y fenesca hasta traer carta executoria. $Y$ nonbramos para que lo traten y prosigan a Hernando Amador de Lezcano, honbre hyjodalgo o quien su poder para ello oviere, que sy es nesçesario le damos poder cunplido bastante para tratar e fenesçer el dicho pleyto e que aya e llebe de su salario por su persona cada un día de los que estubiere e se ocupare en siguimiento del dicho pleito en los caminos que a ydo y que fuere a la Corte, çiento e çincuenta e tres maravedís y en los caminos que fuere a la çibdad de Granada o a otras partes por estas comarcas, que llebe cada día tres reales y medio.

Yten, mandamos elegimos y nonbramos por repartidores para repartir entre nosotros todas las contías de maravedís que fueren menester repartir para tratar e fenesçer el dicho pleito a Gonçalo de los Ríos e a Pedro de Araçola, para que los dichos repartidores, todas las vezes que les paresçiere e vieren que fuere menester repartir entre nosotros / todas las contías de maravedís que ellos vieren que son menester para el dicho pleyto y que hecho el dicho repartimiento, ellos nonbren una persona que bien visto les fuere que en un brebe término que para ello le dieren y que el honbre hijosdalgo que ellos nonbraren sea obligado a lo fazer e cunplir e pagar como los dichos dos repartidores lo mandaren y que a ello no puedan poner escusas ningunas.

Yten, mandamos que todas las vezes que el dicho Fernando Amador quisiere yr personalmente o ynbiar terçera persona al dicho pleito, el que fuere cogedor de los dichos repartimientos sea obligado a le dar todos los dineros que para ello ubiere menester, dándole dineros antes, más que menos, e que el dicho Fernando Amador cada camino de que venga ante los dichos dos repartidores dé quenta de lo que a gastado en el camino y que se le pague todo lo que ubiere gastado y ganado de su salario e que si fuere alcançado en dineros, demás que los dé al dicho cogedor y que si alcançare en dineros que el dicho cogedor sea obligado a se los dar y que por razón que algunas personas vezinos de esta villa son omes hijosdalgo y por escusarse de no pagar ni contribuyr para las costas y gastos del dicho pleyto dizen e publican que no quyeren pleytos ni quyeren entender en el dicho pleyto / y porque el aprovechamiento y derecho que por seguyrse e fenesçerse el dicho pleyto es general, ansí a los omes hijosdalgo vezinos de la dicha villa que agora biben como a sus desçendientes, mandamos que sea notificado y se requ- 
yeran los tales omes fijosdalgo notorios que biben y son vezinos de esta dicha viIla o son nasçidos y naturales de esta dicha villa para tener e pretenden venir a bibir y morar en esta dicha villa, para tener e gozar parte de los dichos ofiçios que den poder al dicho pleito e contribuyan por yguales partes para los dichos gastos $\mathrm{e}$ costas, con protestaçión que hazemos que a los que no lo hizieren a ellos y a sus desçendientes antes que sean admitidos a los dichos ofiçios e suertes pagarán la parte que les pertenesçe conforme a los respartimientos que de oí más se hizieren y gastos y costas que se hizieren e fueren menester fasta traer carta executoria de los dichos ofiçios. E las personas caballeros omes fijosdago que hazemos y nos hallamos en el dicho ayuntamiento e otorgamos lo susodicho y lo de yuso contenido somos los syguientes...

\section{Documento 9}

1543, septiembre, 9

Cuenta dada ante los repartidores hidalgos y los escribanos Juan Moreno y Francisco de Cazorla, de la villa de Cazorla, por Hernando Amador de los gastos hechos en el pleito de mitad de oficios.

ARChG, Hidalguía, Caja 136, pz. 21

\section{Cargo}

-Primeramente, dixo que se le deve y alcançó en la quenta que dio en seys días del mes de abril de mil e quinientos e quarenta e un años, que no se a tomado más quenta hasta agora, que alcançó en diez mil e çiento catorze maravedís. Ponellos por cargo: 10.114 .

-Más hizo cargo que pagó al escrivano de la provança que se hizo en Granada, demás de lo que le dio quando la hizo, quando la sacó, le dio un ducado: 375.

-Más dio que pagó al escrivano de la provança que se hizo en Xódar, demás de lo que le dio quando la hizo, quando la sacó le dio quatro reales: 136.

-Más dio que pagó al escrivano de la provança que se hizo en Guadix, demás de lo que le dio quando la sacó, quatro reales: 136.

-Más dio que pagó en Lezcano al escrivano que hizo la provança, seys reales. No quenta salarios ningunos de yda ni de venyda ni de estada, solamente lo que costó el escrivano: 204.

- Más dio que pagó al escrivano que hizo la provança que se hizo en la villa de Durango, doze reales. No quenta salarios de yda y estada e venida: 408./

-Más dio, que pagó en el Consejo Real al secretario Medina ocho reales de sus derechos para el pleyto de la provisión que se ganó que los hidalgos fuesen admitidos a las suertes y el conçejo suplicó de ella. Dio conoçimiento de la paga. No quenta salarios de yda y estada y venida: 272 . 
- Más dio, que pagó al letrado que le hizo la petiçión echa en el Consejo Real quatro reales. Dio conoçimiento: 136.

-Más dio. que gastó en yr a hazer y acabar de hazer la provança de Quesada, tres días que estuvo personalmente e ansy lo juró, que montan su salario que ganó, diez reales y medio: 302 .

-Más dio, que se ocupó en yr dos o tres vezes a sacar la dicha provança y no se sacó hasta que fue y estuvo e residió en la dicha villa de Quesada seys días e acabó de sacar y se sygnó e se la dieron y la truxo çerrada e sellada en manera que montó su salario, a tres reales y medio cada día, veynte e un reales: 710 .

-Más dio, que gastó e pagó al escrivano de la provança que se hizo en la dicha villa de Quesada, de registro e cada, una vez çinco reales y otra vez, quando se la dio / seys ducados. Mostró conoçimiento de todo. Que montó todo dos mil e quatroçientos e veynte maravedís: 2.420 .

-Más dio, que pagó en la çibdad de Granada al escrivano de unas executorias que le dio sygnadas para presentar en el dicho proçeso, ocho reales. Mostró conoçimiento: 272.

-Más dio, que pagó de la provisyón que se truxo de Granada para que el juez sentençiase el dicho pleito, ocho reales. Dio conoçimiento de ellos: 272.

-Más dio, que pagó a Christóval Garçía, procurador, de su salario de los avtos que hizo en el dicho proçeso, un ducado. Mostró carta de pago: 375.

-Más dio, que pagó de la sobrecarta provisyón para que el juez sentençiase el dicho pleyto al peón, de seys días que estuvo, a real e medio. E de la provisyón ocho reales. Mostró carta de pago: 575.

-Más dio, que fue a la villa de Villacarrillo a hazer uns escriptos de bien provado, porque el bachiller Muñoz no los quisiera hazer, y los hizo el bachiller Tello, y para ello llevó el escrivano de la causa y llevo el proçeso original, diole al bachiller Tello / por los dos escriptos doze reales. E tres días estuvo él allá, uno de yda y otro de estada y otro de venida. Que monta todo y al escrivano se le a de pagar su salario, lo que justo sea: 775 .

- Más dio, que pagó a Juan de Alcaraz que relató el proçeso quando se vido para sentençiallo un ducado. Mostró carta de pago: 375.

- Más dio, que pagó a Pedro de Soto, escriviente, que trasladó una fe del proçeso e sentençia e apelaçión tres reales. Dio conoçimiento de ellos: 105. real: 34 .

-Más dio que pagó al governador de sus derechos de la sentençia, que dio un

-Más dio, que pagó a Diego Hortíz, escriviente, de otra fe y testimonyo de apelaçión de la sentençia para Granada, tres reales: 102. 
-Más dio, que pago a Diego Montero, escriviente, que escrivió una carta al cardenal e otra para el comendador mayor. Escriviolas dos vezes de buena letra. Que le dio dos reales. Mostró carta de pago de ellos: 68.

-Más dio, que pagó a Pedro Palomero, peón, que llevó la apelaçión a la çibdad de Granada e truxo la provisyón çitatoria e compulsoria / veynte e nueve reales de su trabajo e la provisyón. Mostró carta de pago: 986.

- Más dio, que pagó a Juan Ximénez, peón, que fue a la Corte a llevar las cartas y despachos al cardenal e comendador mayor. Que estuvo en yda y estada y buelta veynte e seys días, a dos reales cada día. Mostró carta de pago de ellos. Que son çinquenta e dos reales: 1768.

-Más dos reales que dio a Christóval Espinel, escriviente, porque escrivió el registro del repartimiento que agora se hizo e sacó dos traslados para que lo sygnen los escrivanos. Un traslado para el cogedor y un traslado para que tenga el dicho Hernando Amador. Mostró carta de pago: 68.

-Más seys ducados que dio a Juan Moreno para que començara a sacar el dicho proçeso. Dio conoçimiento de ellos: 2202.

Ansy que monta lo que el dicho Hernando Amador en la manera que dicha es a gastado hasta oy dicho día, veynte e tres mil e dozientos e ochenta e nueve maravedís.

Los quales quitos e descontados los honze mil e çiento e veynte e tres maravedís que Françisco de Bustos, cogedor de los dichos maravedís, dio e pagó al dicho Hernando / Amador, resta y alcança el dicho Hernando Amador a los dichos repartidores y estado de Hijosdalgo todas quentas rematadas en doze mil e çiento e sesenta e seys maravedís. $Y$ ansy se declaró e hizo la dicha quenta en la manera que dicha es. Y lo firmaron los dichos repartidores y el dicho Hernando Amador. Testigos Juan Garçía e Juan Ruiz, ortelanos, e Pablo de Almenara, veçinos de la dicha villa de Caçorla. Gonçalo de los Ríos, Pedro de Ayaçola, Hernando Amador e yo Juan Moreno, escrivano público del número de la dicha villa de Caçorla e uno con los dichos repartidores y testigos, presente fuy a lo susodicho que de suso se haze minçión e por ende fize aquy éste myo signo. En testimonio de verdad, Juan Moreno, escrivano. 